\title{
THE
}

\section{Major shifts in nutrient and phytoplankton dynamics in the North Pacific Subtropical Gyre over the last 5000 years revealed by high- resolution proteinaceous deep-sea coral $\delta^{15} \mathrm{~N}$ and $\delta^{13} \mathrm{C}$ records}

\author{
Danielle S. Glynn \\ Kelton W. McMahon \\ University of Rhode Island, kelton_mcmahon@uri.edu \\ Thomas P. Guilderson \\ Matthew D. McCarthy \\ Follow this and additional works at: https://digitalcommons.uri.edu/gsofacpubs
}

\section{The University of Rhode Island Faculty have made this article openly available.}

Please let us know how Open Access to this research benefits you.

This is a pre-publication author manuscript of the final, published article.

Terms of Use

This article is made available under the terms and conditions applicable towards Open Access Policy Articles, as set forth in our Terms of Use.

\section{Citation/Publisher Attribution}

Glynn, D. S., McMahon, K. W., Guilderson, T. P., \& McCarthy, M. D. (2019). Major shifts in nutrient and phytoplankton dynamics in the North Pacific Subtropical Gyre over the last 5000 years revealed by highresolution proteinaceous deep-sea coral $\delta^{15} \mathrm{~N}$ and $\delta^{13} \mathrm{C}$ records. Earth and Planetary Science Letters, 515, 145-153. doi:

Available at: https://doi.org/10.1016/j.epsl.2019.03.014

This Article is brought to you for free and open access by the Graduate School of Oceanography at DigitalCommons@URI. It has been accepted for inclusion in Graduate School of Oceanography Faculty Publications by an authorized administrator of DigitalCommons@URI. For more information, please contact digitalcommons-group@uri.edu. 
1 Major shifts in nutrient and phytoplankton dynamics in the North

2 Pacific Subtropical Gyre over the last 5000 years revealed by high-

3 resolution proteinaceous deep-sea coral $\delta^{15} \mathrm{~N}$ and $\delta^{13} \mathrm{C}$ records

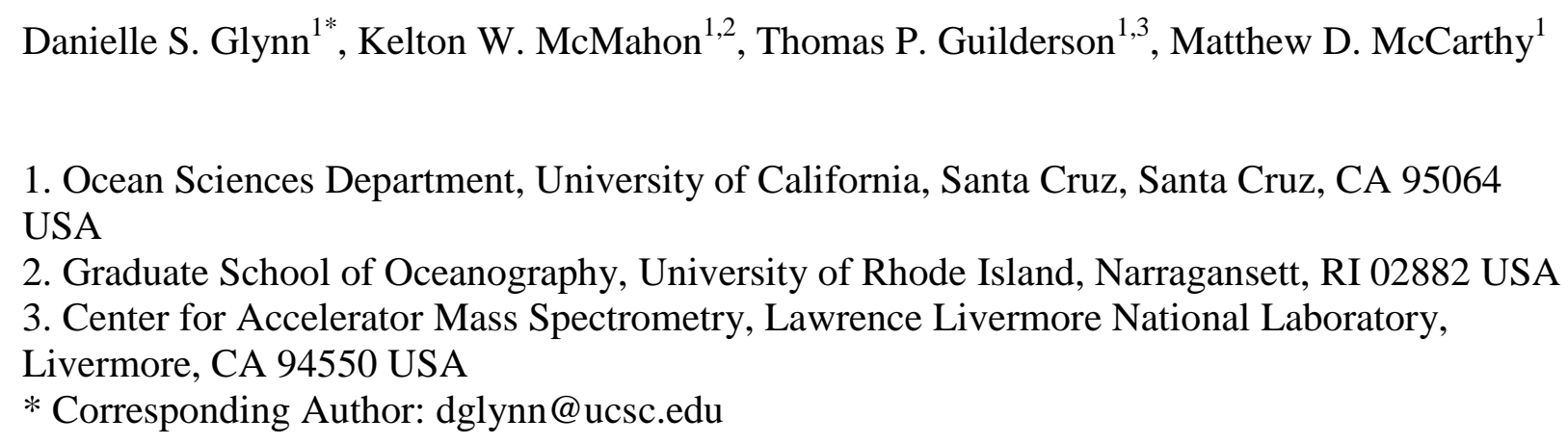




\section{Abstract}

The North Pacific Subtropical Gyre (NPSG) is the largest continuous ecosystem on Earth

17 and is a critical component of global oceanic biogeochemical cycling and carbon sequestration.

18 We report here multi-millennial-scale, sub-decadal-resolution records of bulk stable nitrogen

$19\left(\delta^{15} \mathrm{~N}\right)$ and carbon $\left(\delta^{13} \mathrm{C}\right)$ isotope records from proteinaceous deep-sea corals. Data from three

20 Kulamanamana haumeaae specimens from the main Hawaiian Islands extend coral-based time-

21 series back $~ 5000$ years for the NPSG and bypass constraints of low resolution sediment cores in

22 this oligotrophic ocean region. We interpret these records in terms of shifting biogeochemical

23 cycles and plankton community structure, with a main goal of placing the extraordinarily rapid

24 ecosystem biogeochemical changes documented by recent coral records during the Anthropocene

25 in a context of broader Late-Holocene variability.

26 During intervals where new data overlaps with previous records, there is strong

27 correspondence in isotope values, indicating that this older data represents a direct extension of

28 Anthropocene records. These results reveal multiple large isotopic shifts in both $\delta^{15} \mathrm{~N}$ and $\delta^{13} \mathrm{C}$

29 values similar in magnitude to those reported in last 150 years $\left(\sim 1.5 \%\right.$ or $\delta^{15} \mathrm{~N}$ and $\sim 1.2 \%$ for

30 Seuss-corrected $\delta^{13} \mathrm{C}$ ). This shows that large fluctuations in isotope value of export production in

31 this region are not unique to the recent past, but have occurred multiple times through the Mid-

32 to Late-Holocene. However, these earlier isotopic shifts occurred over much longer time

33 intervals ( millennial vs. decadal time scales). Further, the $\delta^{15} \mathrm{~N}$ data confirm that the extremely

34 low present day $\delta^{15} \mathrm{~N}$ values recorded by deep sea corals $(\sim 8 \%)$ are unprecedented for the NPSG, 35 at least within the past five millennia.

36 Together these records reveal centennial to millennial-scale oscillations in NPSG

37 biogeochemical cycles. Further, these data also suggest a number of independent biogeochemical 
38 regimes during which $\delta^{15} \mathrm{~N}$ and $\delta^{13} \mathrm{C}$ trends were synchronous (similar to recent coral records) or 39 distinctly decoupled. We propose that phytoplankton species composition and nutrient source 40 changes are the dominant mechanisms controlling the coupling and de-coupling of $\delta^{15} \mathrm{~N}$ and $\delta^{13} \mathrm{C}$ 41 values, likely primarily influenced by changing oceanographic conditions (e.g., stratification vs. 42 entrainment). The decoupling observed in the past further suggests that oceanographic forcing 43 and ecosystem responses controlling $\delta^{15} \mathrm{~N}$ and $\delta^{13} \mathrm{C}$ values of export production have been 44 substantially different earlier in the Holocene compared to mechanisms controlling the present 45 day system.

46

47 Key Words: carbon; nitrogen; isotopes; paleoclimate; Holocene; deep-sea coral; North Pacific 48 Subtropical Gyre; phytoplankton; biogeochemical cycling 


\section{Introduction}

52 primary production, with biogeochemical cycles typically dominated by microbial loop

53 dynamics (Karl, 1999). These oligotrophic gyre systems comprise around 60\% of the global

54 oceans and are critical components of the global marine biogeochemical balance (Karl, 1999). It

55 is now recognized that aggregate open-ocean oligotrophic regions, due to their vast extent,

56 contribute the bulk of marine productivity and account for a substantial amount of global ocean

57 export (Karl et al., 1997; Martin et al., 1987).

The North Pacific Subtropical Gyre (NPSG) is the largest contiguous ecosystem on earth,

60 and remote sensing indicates that it is rapidly expanding (Polovina et al., 2008). In contrast to

61 global trends of declining marine productivity, phytoplankton communities of the NPSG are

62 increasing in both biomass and productivity (Boyce et al., 2010; Corno et al., 2007; Karl et al.,

63 2001). This is due to changes in plankton community structure, which appear to be linked to the

64 addition of new nutrient sources from expanding communities of nitrogen-fixing diazotrophs,

65 selected for by increased stratification (Karl et al., 1997; Karl et al., 2001; Karl et al., 2011). As

66 such, understanding how algal community structure and nutrient supply have responded to

67 physical forcing in the past is critical to understanding future changes in the ecosystem dynamics

68 of these critical open ocean systems. As part of the Hawaiian Ocean Time-Series (HOT)

69 program, instrumental observations taken at station ALOHA $\left(22^{\circ} 45^{\prime} \mathrm{W}, 158^{\circ} \mathrm{W}\right)$ suggest that

70 variability in physical and biological attributes of the NPSG are coupled to inter-annual climate

71 variability superimposed upon longer term, basin-wide variability (Corno et al., 2007; Di

72 Lorenzo et al., 2008). While much can be gained from detailed instrumental records at ALOHA 
73 and other time-series stations, the short time scale of these records is inadequate to understand

74 the coupling of biogeochemical cycles to long term climate forcing. Further, the low

75 sedimentation rate in oligotrophic regions, such as the NPSG, means the entire Holocene is

76 recorded in $\sim 10 \mathrm{~cm}$ of bioturbated sediments, leading at best to uncertain, low resolution

77 sediment records.

Cosmopolitan deep-sea proteinaceous corals are unique biogenic archives that can

80 provide centennial to millennial-scale records at sub-decadal resolution of past ocean conditions.

81 These azooxanthellate corals are low-order consumers which feed on recently exported

82 particulate organic matter (POM), and record the isotopic signatures of this food source into the

83 accretionary growth layers of proteinaceous skeletons (Roark et al., 2009; Sherwood et al., 2014;

84 McMahon et al., 2017). The horny proteinaceous skeleton is composed of a fibrillar protein

85 framework (Ehrlich et al., 2006) that is resistant to degradation (Sherwood et al., 2006). The

86 Hawaiian gold coral Kulamanamana haumeaae, a colonial zoanthid, is extraordinarily long-

87 lived, thus providing a bioarchive on multi-millennial time scales for the NPSG region with

88 average radial growth rates in the low tens of microns per year (Guilderson et al., 2013; Roark et

89 al., 2009).

90

91 Previous records from the NPSG Hawaiian Islands spanning the last 1000 years have

92 shown dramatic decreases in both nitrogen $\left(\delta^{15} \mathrm{~N}\right.$; Sherwood et al. 2014) and carbon $\left(\delta^{13} \mathrm{C}\right.$;

93 McMahon et al. 2015) isotopic values since the Little Ice Age ( 1850 CE). These data indicate

94 that both $\delta^{15} \mathrm{~N}$ and $\delta^{13} \mathrm{C}$ values of exported primary production have strongly decreased,

95 commensurate with $20^{\text {th }}$ century warming and gyre expansion. Sherwood et al. (2014) used a 
96 multi-proxy compound-specific stable isotope approach to show that the declining deep-sea coral

$97 \delta \delta^{15} \mathrm{~N}$ values were indicative of an increase in the relative contribution of nitrogen fixation

98 supporting export production in the NPSG over the last 150 yrs. McMahon et al. (2015) then

99 used a compound-specific stable isotope fingerprinting approach to show a concurrent shift

100 towards more $\mathrm{N}_{2}$-fixing cyanobacteria in the phytoplankton community supporting export

101 production over this time period, consistent with the conclusions of Sherwood and co-authors.

102

103 Together, these records indicate dramatic responses in both broad algal community

104 structure and fundamental biogeochemical cycles to shifting climate states of the NPSG.

105 Specifically, these data have suggested: 1) direct coupling in major changes of primary

106 production $\delta^{15} \mathrm{~N}$ and $\delta^{13} \mathrm{C}$ values over the last $\sim 1000$ years, 2) that present primary production

$107 \delta^{15} \mathrm{~N}$ and $\delta^{13} \mathrm{C}$ values are the lowest in at least a millennia, 3) the variability in $\delta^{15} \mathrm{~N}$ and $\delta^{13} \mathrm{C}$ of

108 export production is driven primarily by algal community structure shifts, and 4) that

109 stratification may be a major driver for these changes in plankton community dynamics

110 (Sherwood et al., 2014; McMahon et al., 2015). However, in order to assess these hypotheses

111 within the broader context of the Holocene, longer records are required to better understand the

112 potential drivers for recent variability and to potentially facilitate predictions of ecosystem

113 responses to future change.

115 The main goal of this study was to determine if the dramatic changes documented in the

116 last $150 \mathrm{yrs}$ are in fact unique, and if similar coupled $\delta^{15} \mathrm{~N}$ and $\delta^{13} \mathrm{C}$ shifts are typical on

117 millennial timescales. We report bulk stable nitrogen and carbon isotope records extending into

118 the Mid-Holocene ( $\sim 5000 \mathrm{ybp})$, from proteinaceous deep-sea coral specimens collected from 
119 offshore Oahu, Hawaii. Proteinaceous deep-sea coral skeletons' bulk $\delta^{15} \mathrm{~N}$ and $\delta^{13} \mathrm{C}$ stable

120 isotope values are a reliable proxy of baseline isotope dynamics represented by source and 121 essential amino acid values (e.g., Schiff et al., 2014; Sherwood et al., 2014; McMahon et al., $1222015 ;$ 2017). These new records are used to examine the stability of historical baselines in export 123 production $\delta^{15} \mathrm{~N}$ and $\delta^{13} \mathrm{C}$ values.

\section{Materials and Methods:}

Three sub-fossil K. haumeaae deep-sea coral samples were collected from $400 \mathrm{~m}$ depth

127 offshore of Lanikai on the island of Oahu, Hawaii $\left(21^{\circ} 24.4 \mathrm{~N}, 157^{\circ} 38.6 \mathrm{~W}\right)$. We refer to

128 individual specimens as Lanikai 1, 2, and 3 (L1, L2, and L3) in results and discussion below.

129 Skeletons were washed with seawater then fresh water before being air-dried on deck. Cross

130 section disks $\sim 0.7 \mathrm{~cm}$ thick were cut from close to the basal attachment, polished, and mounted

131 onto glass plates. A computerized Merchanteck micromill was used to isolate 2-3 mg of

132 proteinaceous coral skeleton at $0.1 \mathrm{~mm}$ increments along radial transects from the outer edge to

133 the center.

Bulk $\delta^{15} \mathrm{~N}$ and $\delta^{13} \mathrm{C}$ analyses were conducted on ca. $0.3 \mathrm{mg}$ raw material using a Carlo 136 Erba 1108 elemental analyzer coupled to a ThermoFinningan Delta Plus XP isotope ratio mass 137 spectrometer at the UCSC Stable Isotope Laboratory, following the lab's standard bulk stable 138 isotope protocols (https://websites.pmc.ucsc.edu/ silab/EA_Protocol.php/). Results are reported 139 in conventional per mil (\%) notation relative to air and VPDB standards for $\delta^{15} \mathrm{~N}$ and $\delta^{13} \mathrm{C}$, 140 respectively. Standard laboratory error is $0.2 \%$ for both $\delta^{15} \mathrm{~N}$ and $\delta^{13} \mathrm{C}$, with duplicate coral 141 analyses $(\mathrm{n}=28)$ indicating $0.11 \%$ and $0.14 \%$ reproducibility for $\delta^{15} \mathrm{~N}$ and $\delta^{13} \mathrm{C}$, respectively. 
143 Radiocarbon analyses were performed on 5-7 acid-pretreated sub-samples per specimen.

144 Age-models were determined for each specimen using Bacon, a Bayesian modeling approach,

145 (Blaauw and Christensen 2011), with Marine13 (Reimer et al., 2013). Isotopic regime shifts were

146 detected using the methodology of Rodionov (2004), with a significance level of 0.1 , cut off

147 length of 10, and a Huber's weight parameter of 1 . The regime shift program uses a sequential t-

148 test to determine regimes and can detect shifts in both the mean level of fluctuations and the

149 variance (Rodionov 2004).

151 For comparison with published bulk sediment $\delta^{15} \mathrm{~N}$ records, cores whose chronology

152 were ${ }^{14} \mathrm{C}$ based were updated using Marine13 (Reimer et al., 2013; details in Supplementary

153 file). $\delta^{15} \mathrm{~N}$ records from the NICOPP database (Tesdal et al., 2013) were standardized to a mean

154 of zero for the last 6000 years and datasets were combined to analyze a regional, composite

155 response (Fig. S3, S4). Sediment records were restricted to those that had more than two $\delta^{15} \mathrm{~N}$

156 sampling points in the last six millennia. Simple bivariate linear regressions were performed

157 using JMP Pro ${ }^{\circledR}$ version 12 on both coral and sediment records to examine long-term trends and 158 probabilities.

\section{Results:}

\section{$161 \quad 3.1$ Timescale and resolution}

The $95 \%$ confidence interval for the individual age models averaged $98 \pm 15$ years (Fig.

163 S1, Table S1). The L1 record (1510 to $220 \mathrm{CE}$ ) partially overlaps with the coral record from an 164 adjacent location in Sherwood et al. (2014) but extends the record by nearly 1000 years. L1 had 
165 an estimated average radial growth rate of $14 \mu \mathrm{m} \mathrm{yr}^{-1}$, such that that isotope samples averaged 7 166 yrs. The L2 coral spanned $\sim 565$ years from -20 to -580 CE, with a growth rate of $21 \mu \mathrm{m} \mathrm{yr}^{-1} \mathrm{and}^{-}$ 167 isotope data averaging 5 yrs. L3 was the oldest coral and spanned $\sim 1420$ years from -1540 to 1682960 CE. L3 had an estimated growth rate of $19 \mu \mathrm{m} \mathrm{yr}^{-1}$, with isotope data averaging 5 yrs.

$170 \quad 3.2$ Stable Isotope Results

171 Stable isotope data and C:N ratios as a function of radial distance and age are reported in 172 Supplementary Table S2.

173

\section{$174 \quad 3.3$ Nitrogen Stable Isotopes}

175 L1 $\delta^{15} \mathrm{~N}$ values overlap data from a specimen from nearby Makapu'u, presented in 176 Sherwood et al., (2014), for nearly 300 yrs (Fig. 2A). L1 $\delta^{15} \mathrm{~N}$ values range $2 \%$ from a low of $1778.8 \%$ in $240 \mathrm{CE}$ to a high of $10.8 \%$ in $1440 \mathrm{CE}$. There appear to be $\delta^{15} \mathrm{~N}$ oscillations around an 178 average of $9.4 \pm 0.3 \%(n=82)$ between $220 \mathrm{CE}$ and $580 \mathrm{CE}$, followed by a large increase of $179 \sim 1.2 \%$ from $660 \mathrm{CE}$ to a high of $10.3 \%$ in $680 \mathrm{CE} . \delta^{15} \mathrm{~N}$ values then decline to an average of 9.9 $180 \pm 0.2 \%$ o $(n=66)$ between $710 \mathrm{CE}$ and $1260 \mathrm{CE}$, followed by an increase of $\sim 0.7 \%$ over the next 181 two decades to a new stable period with average values of $10.6 \pm 0.2 \%$ ( $\mathrm{n}=29)$ from $1280 \mathrm{CE}$ 182 until the coral's death in $1510 \mathrm{CE}$.

The L2 coral (-20 to $-580 \mathrm{CE})$ exhibits no clear secular trend but has substantial 185 oscillations (range $\sim 1.6 \%$ ) about the mean $\delta^{15} \mathrm{~N}$ value of $9.2 \pm 0.3 \%$ o $(n=120)$. The end of the L2 186 record (-20 CE) matches within error of the start of L1 300 years later. Regime detection (Fig. 187 S2) notes periods of high $\delta^{15} \mathrm{~N}$ values during -420 to $-450 \mathrm{CE}(9.8 \pm 0.2 \%$, $\mathrm{n}=6)$ as well as -300 
188 to $-340 \mathrm{CE}(9.5 \pm 0.1 \%$, $\mathrm{n}=10)$. The highest $\delta^{15} \mathrm{~N}$ value was $10.0 \%$ ( $\left.-430 \mathrm{CE}\right)$. There was a drop 189 in $\delta^{15} \mathrm{~N}$ values between -190 and $-100 \mathrm{CE}$ to an average of $8.8 \pm 0.4 \%$ ( $\left.\mathrm{n}=18\right)$, and the lowest $190 \quad \delta^{15} \mathrm{~N}$ value was $8.4 \%$ in $-180 \mathrm{CE}$.

191

The Mid-Holocene L3 coral (-1540 to $-2960 \mathrm{CE}$ ) has substantially more positive $\delta^{15} \mathrm{~N}$

193 values $(10.8 \pm 0.3 \%, \mathrm{n}=251)$ compared to all the Late-Holocene and near modern coral data

194 (Fig. 2A). From -2940 to $-2600 \mathrm{CE}$ there is an interval where $\delta^{15} \mathrm{~N}$ increases $\left(0.02 \%\right.$ odecade ${ }^{-1}, \mathrm{R}^{2}$ $195=0.51, \mathrm{p}<0.0001)$ from $10.3 \%$ to $10.9 \%$, despite reaching its lowest value of $10.0 \%$ in a brief 196 excursion near -2720 CE. There is also an apparent step change of $\sim 0.5 \%$ o that occurs around $1972300 \mathrm{CE}$ as values increase from $10.7 \pm 0.1 \%$ ( $(-2390$ to $-2280 \mathrm{CE}, \mathrm{n}=18)$ to $11.2 \pm 0.2 \%$ o $(-2270$ 198 to $-2100 \mathrm{CE}, \mathrm{n}=34)$. After this, values once again return to the coral's overall average, except for 199 a 90 year regime of higher values $(11.1 \pm 0.2 \%, n=20)$ between -1940 and -1840 CE (Fig. S2).

$201 \quad 3.4$ Carbon Isotope Results

202 We observe a $\sim 2 \%$ total range in coral $\delta^{13} \mathrm{C}$ values, with low $\delta^{13} \mathrm{C}$ values very similar to 203 present day occurring multiple times since the Mid-Holocene (in L1 200 CE; in L2 800 BCE; 204 in L3 2800 BCE). L1 coral $\delta^{13} \mathrm{C}$ values ranged over 1.5\% (Fig. 3A), with $\delta^{13} \mathrm{C}$ increasing 205 towards the present. As with the $\mathrm{L} 1 \delta^{15} \mathrm{~N}$ records, there is a significant overlap between the L1 206 coral $\delta^{13} \mathrm{C}$ record and previously published Makapu'u $\delta^{13} \mathrm{C}$ records (McMahon et al., 2015). L1 $207 \delta^{13} \mathrm{C}$ values begin low at $-17.1 \pm 0.1 \%(n=43)$ between $220-460 \mathrm{CE}$, before increasing by $208 \sim 0.4 \%$ over the next few decades to an average of $-16.7 \pm 0.1 \%$ o $(n=119)$ from 480 to $1380 \mathrm{CE}$. 209 Values then rapidly increase by $\sim 1 \%$ o $\left(0.06 \%\right.$ o decade $\left.{ }^{-1}, \mathrm{R}^{2}=0.85, \mathrm{p}<0.0001\right)$, to reach the 210 highest value of $-15.8 \%$ in $1530 \mathrm{CE}$ at the coral's death. 
213 However, in contrast with the relatively stable $\delta^{15} \mathrm{~N}$ record the $\mathrm{L} 2 \delta^{13} \mathrm{C}$ record increases by $1.4 \%$ 214 through this time period (average change of $0.01 \%$ decade ${ }^{-1}, \mathrm{R}^{2}=0.54, \mathrm{p}<0.0001$ ). The $\delta^{13} \mathrm{C}$ 215 values ranged from $-15.5 \%$ o $(-90 \mathrm{CE})$ to $-16.9 \%$ o $(-370 \mathrm{CE})$, and as a whole the L2 record 216 indicates a large isotopic discontinuity in export production $\delta^{13} \mathrm{C}$ values from the end of L2 to the 217 more recent $\mathrm{L} 1 \delta^{13} \mathrm{C}$ record.

The Mid-Holocene L3 record (-1540 to $-2960 \mathrm{CE})$ is also marked by a large and 220 statistically significant, nearly unidirectional, shift of $\sim 2 \%$ in $\delta^{13} \mathrm{C}$ values $\left(0.01 \%\right.$ decade ${ }^{-1}, \mathrm{R}^{2}=$ 221 0.85, $\mathrm{p}<0.0001)$, ranging from -15.2\%o (-1540 CE) to -17.2\%o (-2860 CE) (Fig 3A). Regime 222 detection suggests this increase occurred between plateaus of more constant values, rather than 223 strictly linearly (Fig. S2). Based on regime detection periods, L3 averages $-16.6 \pm 0.1 \%$ (n=49) 224 between -2680 to $-2300 \mathrm{CE}$, increases to $-16.3 \pm 0.1 \%$ o $(-2290$ to $-2080 \mathrm{CE}, \mathrm{n}=41)$, reached a 225 third plateau of $-15.8 \pm 0.1 \%$ o $(-1940$ to $-1630 \mathrm{CE}, \mathrm{n}=64)$, before finally increasing until the 226 record end (Fig. S2). The transition between plateaus around -2300 CE is also coincident with a 227 similar change in $\delta^{15} \mathrm{~N}$ values. In addition, a sharp drop and apparent recovery of $\delta^{13} \mathrm{C}$ values of $228 \sim 0.4 \%$ is observed near the early part of the record around $-2850 \mathrm{CE}$.

\subsection{Coupling vs. Decoupling of Nitrogen and Carbon Isotope Records}

231 The combined isotope records show several distinct periods of coupling where $\delta^{13} \mathrm{C}$ and $232 \delta^{15} \mathrm{~N}$ values trend similarly, corresponding closely to what has been observed in records from this 233 region in the last millennium. However, equally common in the longer Holocene records are 
234 periods where $\delta^{13} \mathrm{C}$ and $\delta^{15} \mathrm{~N}$ variability is decoupled, with either little change in one isotope 235 record corresponding to strong change in the other, or else measured or inferred $\delta^{13} \mathrm{C}$ and $\delta^{15} \mathrm{~N}$ 236 records which trend in opposite directions. Unlike the most recent $\sim 1400$ years where $\delta^{13} \mathrm{C}$ and $237 \delta^{15} \mathrm{~N}$ are coupled, for more than a thousand years (-580 to $\left.670 \mathrm{CE}\right)$ the $\delta^{13} \mathrm{C}$ and $\delta^{15} \mathrm{~N}$ values are 238 generally decoupled, suggesting a different regime than modern (Fig. 4, "DC1", representing L2 239 and part of L1 corals). As noted previously, the $\delta^{15} \mathrm{~N}$ values throughout this same period (-580 to

$240670 \mathrm{CE}$, including the gap between L1 and L2 records) remained relatively constant (mean of 9.3

$241 \pm 0.3 \%$ ), while in contrast the $\delta^{13} \mathrm{C}$ values increased in L1 and L2 corals (from -430 to $-20 \mathrm{CE}$

242 and 250 to $670 \mathrm{CE})$, with an additional large decline in $\delta^{13} \mathrm{C}$ values $(\sim 1 \%)$ required to connect

243 values between these two records. Further back in the $\sim 1000$ year period between L3 and L2

244 (Fig. 4, "C2"), the offset between coral records indicates an overall shift in both $\delta^{15} \mathrm{~N}$ and $\delta^{13} \mathrm{C}$ to 245 much lower values from past to present. The Mid-Holocene trends in $\delta^{13} \mathrm{C}$ and $\delta^{15} \mathrm{~N}$ values 246 appear to have become decoupled once again from -2550 to $-1540 \mathrm{CE}$, with $\delta^{15} \mathrm{~N}$ values 247 averaging $10.9 \pm 0.3 \%$, while $\delta^{13} \mathrm{C}$ values increase by $\sim 1.5 \%$. Finally, in the earliest part of 248 these coral records (-2950 to $-2550 \mathrm{CE})$, both $\delta^{15} \mathrm{~N}$ and $\delta^{13} \mathrm{C}$ values again trend in the same 249 direction.

251 4. Discussion

\section{4.1 Nitrogen Isotopic Records}

253 The records exhibit a surprisingly wide range in $\delta^{15} \mathrm{~N}$ values of about $3.5 \%$, marked by 254 several distinct regimes, with the most positive $\delta^{15} \mathrm{~N}$ values seen in the Mid-Holocene and lowest 255 in the present day (Fig. 2). Using this new $5000 \mathrm{yr} \delta^{15} \mathrm{~N}$ dataset for context, it is clear that the 256 rate of the post- 1850 decline $(1.5 \%$ in $150 \mathrm{yrs})$ is significant and unique. More common in the 
257 coral data are long periods of relative stability, with millennial-scale plateaus of similar $\delta^{15} \mathrm{~N}$

258 values in three intervals (from approximately -2960 to -1540 CE, -580 to $660 \mathrm{CE}$, and from 660

259 to the 1800s; Fig. 2). While there is no direct coral data for the millennial-scale gap from -1530

260 to -580 , the offset between L2 and L3 indicates that a $\sim 1.5 \%$ shift in $\delta^{15} \mathrm{~N}$ must have occurred in

261 this period. If this inference is correct, this would represent a shift in $\delta^{15} \mathrm{~N}$ value of export

262 production similar in magnitude to the change in the last 150 years, but potentially over 1000

263 years (Fig. 2).

264

265 Since nitrate is fully utilized on an annual scale in the NPSG, isotope mass balance 266 requires that the overall $\delta^{15} \mathrm{~N}$ value of autotrophs represents an integrated signal of the $\delta^{15} \mathrm{~N}$

267 value of their nitrogen sources. Thus, gyre-based paleo- $\delta^{15} \mathrm{~N}$ records can be interpreted in terms 268 of the relative balance of isotopically distinct nutrient sources supporting export production (e.g., 269 Altabet et al. 2006; Dore et al. 2002; Sherwood et al 2014). The large $\sim 3.5 \%$ variability in $\delta^{15} \mathrm{~N}$ 270 values recorded in these corals could therefore be driven by either changing phytoplankton 271 communities (i.e., relative importance of diazotroph $\mathrm{N}_{2}$-fixation), and/or shifts in the source $\delta^{15} \mathrm{~N}$ 272 value of advected nitrate. This latter aspect includes both the water mass being entrained during 273 mixing as well as $\delta^{15} \mathrm{~N}_{\mathrm{NO} 3}$ values sourced from the margins. Both situations could have been 274 influenced by changes in water column stability and ocean-biogeochemistry dynamics.

In the NPSG near the Hawaiian islands nitrogen fixation leads to characteristically low $277 \delta^{15} \mathrm{~N}$ values $(\sim 0 \%)$ in the upper euphotic zone, while mesopelagic nitrate sources have much 278 higher values (Dore et al., 2002; Casciotti et al., 2008). By assuming mass balance based on a 279 two-component mixing model, with $\delta^{15} \mathrm{~N}_{\mathrm{N} 2-\mathrm{fix}}=0 \%$ and $\delta^{15} \mathrm{~N}_{\mathrm{NO} 3}=6.5 \%$, and a sinking 
280 particulate bulk $\delta^{15} \mathrm{~N}$ value of $3.5 \pm 0.2 \%$ at $300 \mathrm{~m}$ (Casciotti et al., 2008; Dore et al., 2002; Karl

281 et al., 1997), around half ( 46\%) of present-day exported production is supported by $\mathrm{N}_{2}$ fixation.

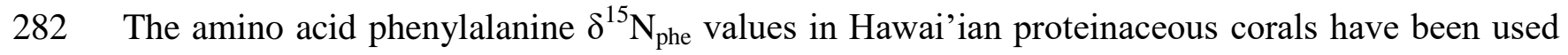

283 as a proxy for baseline nitrate and average $2.5 \pm 0.3 \%$ over the late $20^{\text {th }}$ and early $21^{\text {st }}$ century

284 (n=7; Sherwood et al., 2014; McMahon et al., 2017), which implies a similar, albeit slightly

285 higher ( 60\%) fraction of export production supported by nitrogen fixation. As documented by

286 Sherwood et al., 2014, there is a very strong 1:1 relationship $\left(\mathrm{R}^{2}=0.77\right)$ between bulk skeleton

$287 \delta^{15} \mathrm{~N}$ and $\delta^{15} \mathrm{~N}_{\text {phe }}$ in $K$. haumeaae. Assuming that this 1:1 covariance is maintained in these

288 specimens, it is possible to directly transform (interpret) changes in bulk coral $\delta^{15} \mathrm{~N}$ into baseline

289 variability.

291 Water column denitrification discriminates strongly against the heavier ${ }^{15} \mathrm{~N}$ isotope,

292 leaving seawater nitrate more positive in ${ }^{15} \mathrm{~N}$, and ocean circulation patterns can transport this

293 isotopic signal throughout the Pacific (Altabet, 2006; Sigman et al., 2009). Analysis of North

294 Pacific sediment records $(n=30)$ indicates an overall decline of $\sim 0.5 \%$ in bulk sediment $\delta^{15} \mathrm{~N}$

295 values since the Mid-Holocene (Fig. S3, S4). The decline in sedimentary $\delta^{15} \mathrm{~N}$ is assumed to

296 reflect changes in overlying nitrate values and has been attributed to a decline in water column

297 denitrification through the Holocene ( $\mathrm{Jia}$ and $\mathrm{Li}, 2011$ and references therein). However, a

298 gradual $\sim 0.5 \%$ o decline in whole North Pacific Ocean $\delta^{15} \mathrm{~N}_{\mathrm{NO} 3}$ values clearly cannot be the

299 primary driver of $\delta^{15} \mathrm{~N}$ values in our coral records, which exhibit significant variability in $\delta^{15} \mathrm{~N}$

300 values rather than monotonic changes. There is also little variability in sedimentary $\delta^{15} \mathrm{~N}$ values

301 from source regions of the Eastern Pacific that intersect water-masses (isopycnals) ventilating the

302 NPSG interior (Fig. 2C), which corresponds to variability in $\delta^{15} \mathrm{~N}$ export production as 
reconstructed by coral data. We are thus left with two potential mechanisms that drive the

304 variability we observe. The first is a change in plankton community structure with variable

305 importance of nitrogen fixing diazotrophs and the second is a change in the source of water being

306 entrained into the mixed layer that provides nitrate to the NPSG. It is likely that the physical

307 forcing for these two aspects is related: a more stratified ocean has diminished input from deeper

308 water masses and could provide an expanded niche for diazotrophs (Karl et al., 2001; McMahon

309 et al., 2015).

Mid-Holocene $\delta^{15} \mathrm{~N}$ values from the L3 specimen average $10.8 \%$ with sustained positive

312 values in excess of $11 \%$. Within the context of the modern endmember model previously

313 discussed, a value of $11 \%$ implies that $\sim 80 \%$ of the export production is supported by subsurface

314 nitrate (ie., only 20\% supported by nitrogen fixation). Specimens L3 and L2 (-1530 to -580 CE)

315 would suggest an increase in the contribution of $\mathrm{N}_{2}$-fixation to export production across this gap

316 with the source apportionment reaching close to equal. From $\sim 580 \mathrm{BCE}$ to the beginning of the

317 Little Ice Age $(\sim 1450 \mathrm{CE})$, a return to production supported more by nitrate $(\sim 70 \%)$ than

318 nitrogen fixation ( $\sim 30 \%)$ appears likely. If the entrained nitrate was sourced from deeper in the

319 water column, the apportionment difference between $\mathrm{NO}_{3}{ }^{-}$and $\mathrm{N}_{2}$-fixation would become less.

320 That being said, the data require 1) simply a higher concentration of $\mathrm{NO}_{3}{ }^{-}$sourced from similar

321 present-day depth, 2) more positive $\delta^{15} \mathrm{~N}_{\mathrm{NO} 3}$ entrained from deeper isopycnals or 3) a different

322 source origin. Deepening of the mixed-layer due to cooling and/or more frequent storm events

323 (windiness) is an obvious mechanism to reduce stratification and increase the vertical flux of

$324 \mathrm{NO}_{3}{ }^{-}$into the mixed-layer. In the modern NPSG, stratification is the most common underlying

325 driver associated with shifts in diazotroph communities and rates of nitrogen fixation (Karl et al., 
2001). Increased rates of $\mathrm{N}_{2}$-fixation with abundant populations of Trichodesmium have been

327 found to occur during the warm phase of El Niño Southern Oscillation (ENSO; Karl et al., 1995;

328 Corno et al., 2007) when persistent subsidence leads to decreased cloud cover, rainfall, and

329 storminess in the Hawai'ian Islands (Chu and Chen, 2005; Diaz and Giambelluca, 2012.). A

330 coupling of warm sea surface temperatures and increased stratification is likely associated with

331 less cloudiness and reduced storminess, which should correspond to lower $\delta^{15} \mathrm{~N}$ values. Thus, on

332 millennial timescales, the balance of nitrogen supporting export production likely reflects the

333 large-scale circulation associated with the migration of the descending limb of the Hadley Cell

334 and the Intertropical Convergence Zone (ITCZ) that follows summer insolation (Fig. 2).

Solar forcing influences the position of the ITCZ by modulating its latitudinal extent,

337 with a concomitant influence on ENSO variability (Clement et al., 2000; Schneider et al., 2014;

338 Lu et al., 2018). Sediment data suggests $\delta^{15} \mathrm{~N}$ varies by latitude, with more positive $\delta^{15} \mathrm{~N}$ values

$339(\sim 2.5 \%)$ offshore of Mexico in comparison to near the equator (Fig. 2C). A southward shift of

340 the ITCZ is expected to enhance equatorial upwelling (Schneider et al., 2014). On millennial

341 timescales when the ITCZ is more southward during the Late-Holocene, it may be that

342 comparatively more negative $\delta^{15} \mathrm{~N}$ waters are advected to the NPSG. While there are some

343 discrepancies between ENSO proxy records due to sparse data sampling and proxy-record

344 specific assumptions, there is general agreement on a reduction in interannual ENSO variability,

345 including amplitude, 4-5 kyrs BP and increases in ENSO variability between 1-2 kyrs BP (Lu et

346 al., 2018 and references therein). Although our records are too coarse to capture interannual

347 variability, we can explore the multidecadal variability that impacts SSTs and storminess

348 (precipitation) in the Hawai'ian Islands (Karl et al. 1995; Chu and Chen, 2005; Diaz and 
349 Giambelluca, 2012). Spectral analysis did not reveal consistent multi-decadal to centennial scale

350 power in the Lanikai data and while the detected regimes $(n=29)$ did not often overlap in timing

351 between $\delta^{15} \mathrm{~N}$ and $\delta^{13} \mathrm{C}$ records (Fig. S2), most regimes ( $\sim 60 \%$ ) tended to last between 30 and 90

352 years in duration. We posit that the regime analysis is confirming multi-decadal variability, but

353 the mechanistic forcing cannot yet be precisely elucidated.

\subsection{Carbon Isotopic Records}

The $\sim 2 \%$ range in coral $\delta^{13} \mathrm{C}$ values across our $5000 \mathrm{yr}$ record also appear to occur

357 within a number of discrete cycles in $\delta^{13} \mathrm{C}$ values of export production, with low $\delta^{13} \mathrm{C}$ values

358 similar to present day having occurred multiple times since the Mid-Holocene (in L1 $200 \mathrm{CE}$;

359 in L2 $800 \mathrm{BCE}$; in L3 $2800 \mathrm{BCE}$ ). Bulk coral $\delta^{13} \mathrm{C}$ values have a strong, positive relationship

360 with essential amino acid $\delta^{13} \mathrm{C}$ values in $K$. haumeaae, particularly the $\delta^{13} \mathrm{C}$ value of

361 phenylalanine $\left(\mathrm{R}^{2}=0.69\right.$, McMahon et al. 2015), which indicates that most bulk $\delta^{13} \mathrm{C}$ variability

362 can be tied to changes in the source carbon at the base of the food web. However, it should be

363 noted that variations in bulk $\delta^{13} \mathrm{C}$ values are typically muted in magnitude compared to the $\delta^{13} \mathrm{C}$

364 signal from essential amino acids (Schiff et al. 2014; McMahon et al., 2015), thus suggesting

365 bulk coral $\delta^{13} \mathrm{C}$ records may underestimate the full extent of variability in baseline export 366 changes.

368 There are multiple factors influencing planktonic $\delta^{13} \mathrm{C}$ values in the marine environment, 369 but on long timescales the dominant controls include SST, ambient $\mathrm{CO}_{2}$ (aq.) concentrations, the $370 \delta^{13} \mathrm{C}$ of dissolved organic carbon (DIC), and taxon-specific fractionation values ( $\left.\varepsilon_{\mathrm{f}}\right)$ (Rau et al., 371 1996; Young et al., 2013; McMahon et al., 2015). Given that these factors can be inter-linked, 
372 definitively assigning causes to past changes in export production $\delta^{13} \mathrm{C}$ values is challenging.

373 Consideration of both past paleo-reconstructions and modern experiments on the effects of main

374 physical forcings (temperature, $\mathrm{pCO}_{2}$, atmospheric $\delta^{13} \mathrm{C}$ ) can help to refine potential 375 interpretations. Increased $\mathrm{CO}_{2}$ availability, whether through increased external $\mathrm{CO}_{2}$ 376 concentrations or increases in [DIC], generally results in decreased $\delta^{13} \mathrm{C}$ values and a greater 377 discrimination between the phytoplankton and source $\mathrm{CO}_{2}$ (Rau et al., 1989; Young et al., 2013). 378 However, from the Mid-Holocene to the Little Ice Age, the concentration of $\mathrm{CO}_{2}$ in the 379 atmosphere has increased by only $\sim 10 \mathrm{ppm}$, with little to no change in atmospheric $\delta^{13} \mathrm{C}$ (fig. 3; 380 Monnin et al., 2004), suggesting that the signal being recorded in these corals is not mainly due 381 to $\mathrm{pCO}_{2}$ change. The low sensitivity of plankton $\delta^{13} \mathrm{C}$ to changes in $\mathrm{pCO}_{2}\left(0.0003 \% \mathrm{ppm}^{-1}\right.$; 382 Young et al. 2013) would further indicate that atmospheric $\delta^{13} \mathrm{C}$ value is not a main driving 383 mechanism for the large changes in our coral records. Baseline changes in the $\delta^{13} \mathrm{C}$ of DIC are 384 also likely to be too small to be driving the trends in coral $\delta^{13} \mathrm{C}$ (Quay and Stutsman, 2003; 385 Monnin et al., 2004).

Laboratory and field experiments document that temperature exerts a significant control 388 on phytoplankton and exported organic matter $\delta^{13} \mathrm{C}$ values (Table S3, and associated references). 389 In general, warmer conditions contribute to more positive exported organic $\delta^{13} \mathrm{C}$ values. Multiple 390 approaches have attempted to quantify the effects of temperature on the $\delta^{13} \mathrm{C}$ values of primary 391 production, including: estimates of the effect of temperature on fractionation factors in culture $392\left(\varepsilon_{\mathrm{p}} ;+0.12 \% /{ }^{\circ} \mathrm{C}\right)$ and on phytoplankton $\delta^{13} \mathrm{C}\left(+0.11-0.23 \% /{ }^{\circ} \mathrm{C}\right)$ and suspended particulate 393 organic carbon $\delta^{13} \mathrm{C}\left(+0.41 \%{ }^{\circ} \mathrm{C}\right)$ in natural ocean systems. Mid- to Late-Holocene SST 394 estimates using both the Modern Analog Technique and alkenone-SST relationships in sediment 
395 cores near Oahu indicate temperatures within $1{ }^{\circ} \mathrm{C}$ of early $20^{\text {th }}$ century data (Lee et al., 2001).

396 These estimates are similar to higher resolution Northern Hemisphere reconstructions (e.g., Pei

397 et al. 2017). A $\leq 1^{\circ} \mathrm{C}$ SST change would only account for $\sim 0.4 \%$ or less of the $2 \% 0 \delta^{13} \mathrm{C}$

398 variability, suggesting temperature alone is only partially responsible for the trends in coral $\delta^{13} \mathrm{C}$.

$400 \quad$ Shifting plankton community composition, implicitly including size/morphology and

401 growth rate, is the most likely explanation for the large changes in $\delta^{13} \mathrm{C}$ values of our coral

402 records over the last 5000 yrs. Different phytoplankton species have unique carbon isotope

403 fractionations during photosynthesis (Laws et al., 1995; Rau et al., 1996), and thus a shifting

404 phytoplankton community composition can be a major driver behind changes in $\delta^{13} \mathrm{C}$ of export

405 production over time (McMahon et al., 2015). Prokaryotic cyanobacteria (e.g., Prochlorococcus,

406 Synechococcus) and picoeukaryotes are typically the dominant phytoplankton groups in open

407 ocean regions like the NPSG (e.g., Karl et al., 2001), and of these, Synechoccocus and

408 picoeukaryotes are most strongly associated with carbon export in oligotrophic regions (Guidi et

409 al. 2016). Picoeukaryotes are also larger than prokaryotes (cell diameters of 2.0 and $0.5 \mu \mathrm{m}$

410 respectively) and this contributes to differences in their ecological performance as well as the

411 extent of carbon fixation and export (Massana and Logares 2013). Based on distinct isotopic

412 fractionations associated with enzymatic, intracellular carbon fixation $\left(\varepsilon_{\mathrm{f}}\right.$; Laws et al., 1995;

413 Scott et al., 2007), the differences between prokaryotic and eukaryotic contributions to exported

414 organic matter manifest as differences in $\delta^{13} \mathrm{C}$ values: where $\sim 0.6 \%$ of $\delta^{13} \mathrm{C}$ variability can be

415 explained by a $1 \%$ shift in community fractionation $\varepsilon_{\mathrm{f}}$ (Table S3). More positive $\delta^{13} \mathrm{C}$ values

416 indicate higher relative contributions of eukaryotic phytoplankton, consistent with the well- 
417 known general trend that larger phytoplankton cells (e.g. diatoms) express more positive $\delta^{13} \mathrm{C}$

418 values than small-celled nanoplankton (e.g., Laws et al., 1995; Popp et al. 1998).

Coral $\delta^{13} \mathrm{C}$ values suggest centennial to millennial scale trends towards increasing 421 eukaryotic contributions in exported production followed by hypothesized events (e.g. between

422 L3 and L2) that reset the NPSG to be more prokaryotic-dominated. Picoeukaryotes are 423 metabolically less flexible than prokaryotic organisms, perhaps causing them to be less resilient 424 to environmental changes (Massana and Logares, 2013). Prokaryotic $\mathrm{CO}_{2}$ fixers also outgrow 425 and outperform eukaryotes in oligotrophic gyre ecosystems (Zubkov 2013), which suggests that 426 during periods of stratified, nutrient-limited conditions, prokaryotic organisms may dominate 427 primary production and thus export production in the NPSG. The stability of the water column 428 due to the frequency of ENSO events may influence community structure, with periods of low 429 ENSO activity (e.g., $3.5-5$ kyrs ago) allowing for a long term community increase of eukaryotic 430 organisms. This would result in the observed steadily increasing $\delta^{13} \mathrm{C}$ values of coral L3), while 431 periods of high ENSO activity (e.g. 1-2 kyrs ago and 3-4 kyrs ago; Moy et al. 2002, Fig. 3) 432 would correspond to a community consistently dominated by prokaryotes and low, stable $\delta^{13} \mathrm{C}$ 433 values (averaging $-16.9 \pm 0.2 \%$ from 200 to $1000 \mathrm{CE}$, Fig. 3). Shifts between smaller celled 434 prokaryotes and larger picoeukaryotes can modulate the amount of organic matter exported to 435 depth and may cause cascading effects on pelagic and benthic food webs (Finkel et al. 2010).

\subsection{Coupling vs. Decoupling of export production $\delta^{15} \mathbf{N}$ and $\delta^{13} \mathrm{C}$ values}

438 Existing records from deep-sea corals from the NPSG in the last 1000 yrs have uniformly 439 documented coupled changes in $\delta^{15} \mathrm{~N}$ and $\delta^{13} \mathrm{C}$ values at the base of the food web, with authors 
440 hypothesizing that such shifts are linked to recent shifts in local/regional temperature and the 441 ecosystem response derived from the dynamical oceanographic setting coincident with warmer 442 surface temperatures (e.g., Sherwood et al., 2014; McMahon et al., 2015). Therefore, the 443 observation that in the longer Holocene record, relative changes in $\delta^{15} \mathrm{~N}$ and $\delta^{13} \mathrm{C}$ values of 444 export production often trend in opposite directions was unexpected. The $\delta^{15} \mathrm{~N}$ and $\delta^{13} \mathrm{C}$ data 445 from these coral specimens, including the required changes necessary to bridge gaps between 446 records, clearly indicate three periods in which changes in $\delta^{15} \mathrm{~N}$ and $\delta^{13} \mathrm{C}$ values are largely 447 synchronous (moving in the same direction, with generally similar slopes), and two periods in 448 which values appear decoupled (Fig. 4; Results 3.5). This suggests a more complex set of 449 biogeochemical forcings on the longer time scales of these records.

452 shifts is one of the most striking overall features (Fig. 4). This observation supports the 453 conclusion that regional plankton community changes are the underlying driver for changes 454 observed in isotope records, primarily reflecting shifts between a more stable water column 455 promoting oligotrophic and $\mathrm{N}_{2}$-fixation conditions versus cooler periods with increased vertical 456 mixing and entrainment (Sherwood et al., 2014; McMahon et al., 2015). Specifically, more 457 recent warmer periods are characterized by more stratified and nutrient-poor conditions with 458 enhanced nutrient recycling and fewer large eukaryotic cells (e.g., Chavez et al., 2011). Such 459 conditions favor microbial-loop dominated systems characterized by lower $\delta^{13} \mathrm{C}$ values. The 460 enhanced $\mathrm{N}_{2}$-fixation and nutrient recycling in such systems also leads to lower $\delta^{15} \mathrm{~N}$ values, 461 accounting for linked $\delta^{15} \mathrm{~N}$ and $\delta^{13} \mathrm{C}$ changes. Conversely, higher nutrient environments are 
462 typified by faster growing, larger eukaryotic autotrophs supported by upwelled nitrate, leading to 463 concurrent increases in both $\delta^{15} \mathrm{~N}$ and $\delta^{13} \mathrm{C}$ primary production values.

The decoupling of $\delta^{15} \mathrm{~N}$ and $\delta^{13} \mathrm{C}$ changes in earlier periods of this $\sim 5000 \mathrm{yr}$ record

466 suggest distinctly different local to basin-scale drivers for $\delta^{15} \mathrm{~N}$ and $\delta^{13} \mathrm{C}$ values. While earlier 467 data indicate several periods of coupled $\delta^{15} \mathrm{~N}$ and $\delta^{13} \mathrm{C}$ change in the NPSG that appear to be 468 analogues to the recent millennium, the distinct periods of coupling and decoupling must indicate 469 different mechanisms are driving changes in primary production $\mathrm{N}$ and $\mathrm{C}$ cycles. The two 470 periods of decoupled isotopic behavior (Fig. 4, DC1, DC2) occur when hemispheric 471 temperatures may have been $\sim 0.5^{\circ}$ cooler than present (Pei et al., 2017) and proxy records 472 suggest reduced ENSO climate variability (Lu et al. 2018; Moy et al. 2002). In contrast, the 473 coupled period C1 includes the warmer Industrial Revolution and Medieval Climate Anomaly 474 where proxy records agree on enhanced ENSO conditions (Lu et al. 2018 and references therein), 475 while the $\mathrm{C} 2$ period roughly corresponds to the end of northern hemisphere neoglaciation. Both 476 C2 and C3 occur during enhanced ENSO activity periods as characterized by some proxy records 477 (e.g. Moy et al. 2002, Fig 3). One hypothesis for this apparently contrasted behavior is that 478 coupling versus decoupling may be related to relative regional sea surface temperatures and 479 stratification. Cooler periods of reduced ENSO variability are decoupled in $\delta^{15} \mathrm{~N}$ and $\delta^{13} \mathrm{C}$ values, 480 while warmer, enhanced ENSO periods are more consistently coupled. While speculative, this 481 could be due to changing nutrient regimes. Generally warmer SSTs correspond to enhanced 482 ocean stratification, shallower mixed layer depths, and a slowdown in gyre circulation. Under 483 such oligotrophic conditions, phytoplankton communities may rely more heavily on the supply 484 of $\mathrm{N}_{2}$-fixed nitrate from localized diazotroph production, and community composition may shift 
485 towards prokaryotic, $\mathrm{N}_{2}$-fixing organisms, perhaps causing a coupling in $\delta^{13} \mathrm{C}$ and $\delta^{15} \mathrm{~N}$ values of 486 export production. In contrast, there is both more mixing from depth and/or enhanced lateral 487 advection of water from ocean margins during cooler, often windier, climatic periods (Sigman et 488 al. 2009). The result is lower rates of $\mathrm{N}_{2}$-fixation (Galbraith et al., 2004) and more nitrate with 489 more positive $\delta^{15} \mathrm{~N}$ values possibly advected from higher latitudes of the Eastern Pacific. Thus, 490 community composition changes may serve to shift $\delta^{13} \mathrm{C}$ values, while the signal of advected

$491 \delta^{15} \mathrm{~N}_{\mathrm{NO} 3}$ and not $\mathrm{N}_{2}$-fixation drives the $\delta^{15} \mathrm{~N}$ value of exported organic matter during periods of 492 cooler SSTs, thus decoupling the $\delta^{13} \mathrm{C}$ and $\delta^{15} \mathrm{~N}$ values. McMahon and coauthors (2015) supports 493 this idea, suggesting nitrate utilizing cyanobacteria dominate community composition over some 494 periods while $\mathrm{N}_{2}$-fixating cyanobacteria dominate over others during the most recent millennium. 495 While this idea cannot be directly tested using bulk isotope analysis, further work could address 496 it.

\section{5. Conclusions}

499 This study documents variability in export production $\delta^{15} \mathrm{~N}$ and $\delta^{13} \mathrm{C}$ values for the 500 Holocene NPSG, extending previously published records by approximately 4000 years deeper 501 into the Mid-Holocene. These new data reveal a dynamic biogeochemical system, in which 502 substantial changes in $\delta^{15} \mathrm{~N}$ and $\delta^{13} \mathrm{C}$ values of export production have been common on 503 millennial time scales. Our records indicate that the natural (preindustrial era) isotopic range of 504 production in the NPSG has varied by up to $3.5 \%$ for $\delta^{15} \mathrm{~N}$ values and $2 \%$ for $\delta^{13} \mathrm{C}$ values over 505 the last $5000 \mathrm{yrs}$. In particular, Mid-Holocene export production $\delta^{15} \mathrm{~N}$ values appear to have been 506 substantially higher (by $\sim 1.5$ to $2 \%$ ) than in the Late-Holocene, and these longer records confirm 507 that present day $\delta^{15} \mathrm{~N}$ values recorded in corals $(\sim 8 \%)$ are the lowest in $\sim 5000$ years. In contrast, 
508 low $\delta^{13} \mathrm{C}$ values similar to those recorded in modern corals $(\sim-17 \%)$ were reached during at least 509 two other periods since the Mid-Holocene.

512 the last 5000 years similar in magnitude to changes in the Anthropocene, past changes appear to 513 have occurred over much longer ( millennial) timescales. In addition, these new records also 514 indicate that distinct periods of coupled and decoupled $\delta^{15} \mathrm{~N}$ and $\delta^{13} \mathrm{C}$ dynamics occurred in 515 different periods throughout the Holocene. This in turn suggests a number of independent 516 biogeochemical regimes over the last 5000 yrs. We hypothesize that these regimes are most 517 likely linked to shifts in plankton community structure, possibly coupled with independently 518 varying $\delta^{15} \mathrm{~N}$ values of nitrate in this region. The coupled $\delta^{15} \mathrm{~N}$ and $\delta^{13} \mathrm{C}$ periods are similar to 519 shifts observed in both NPSG instrumental records and also in more recent coral chronologies, 520 likely explained by relative importance of nitrogen fixation and upper water stratification 521 (McMahon et al., 2015; Sherwood et al., 2014). Periods in which $\delta^{13} \mathrm{C}$ values change with no 522 major shifts $\delta^{15} \mathrm{~N}$ values imply changes in phytoplankton community structure without clear 523 linkage to shifts in nutrient supply, potentially explained by relative abundance of non-nitrogen 524 fixing prokaryotic autotrophs in this region (McMahon et al. 2015). However, to test these ideas 525 more work will be necessary to identify the relative influence of baseline nutrient supply vs. 526 changes in autotrophic community structure.

Overall, the dynamism of Holocene biogeochemical systems revealed by this study 529 strongly emphasizes the need to develop new proxies that can be used to determine past climate 530 and environmental conditions at high resolution in the NPSG. Future work should include 
531 compound specific analysis of amino acids within coral archives to further constrain these

532 hypotheses. Such information would allow researchers to directly examine if present microbial-

533 loop dominated system of the NPSG has been constant or if variation in community structure has

534 been responsible for isotopic variability of our records earlier in the Holocene. Further, this

535 approach would allow for testing of the underlying assumption that average trophic structure of

536 NPSG planktonic systems, which strongly influences the $\delta^{15} \mathrm{~N}$ value of export production, has

537 remained constant through time. While data from Sherwood et al. (2014) indicated that average

538 planktonic ecosystem trophic position has remained constant over the most recent millennium, it

539 is not known if this also would hold true for earlier parts of this record, specifically during

540 periods of $\delta^{13} \mathrm{C}$ and $\delta^{15} \mathrm{~N}$ decoupling. Regardless, we show that while NPSG plankton and

541 nutrient dynamics are highly variable over the last $5000 \mathrm{yrs}$, the modern anthropoence regime

542 remains unique in the magnitude and timing of changes in ecosystem dynamics in the context of

543 Holocene variability.

545 Acknowledgements:

546 None of this work would have been possible without the captain and crew of the RV

547 Ka 'imikai-o-Kanaloa and the pilots and engineers of the Hawaii Undersea Research Lab's Pisces

548 IV and V. Sample collection was funded by NOAA/NURP and the National Geographic Society

549 (7717-04). A portion of this work was performed under the auspices of the U.S. Department of

550 Energy (DE-AC52-07NA27344). The majority of the work presented here was funded by the

551 NSF (OCE 1061689). D.S. Glynn was supported by a Cota Robles and NSF GRFP Fellowship.

552 Further thanks go to D. Andreasen, C. Carney, R. Franks, and J. Schiff for laboratory assistance 553 and training. 


\section{References:}

555 Altabet, M.A., 2006. Isotopic Tracers of the Marine Nitrogen Cycle: Present and Past. Hdb Env Chem 2, 251-293. https://doi.org/10.1007/698_2_008

Berger, A., Loutre, M.F., 1991. Insolation values for the climate of the last 10 million years.

Quat. Sci. Rev. 10, 4, 297-317. https://doi.org/10.1016/0277-3791(91)90033-Q

Blaauw, M., Christen, J.A., 2011. Flexible paleoclimate age-depth models using an autoregressive gamma process. Bayesian Anal. 6, 457-474. https://doi.org/10.1214/11BA618

Boyce, D.G., Lewis, M.R., Worm, B., 2010. Global phytoplankton decline over the past century. Nature 466, 591-596. https://doi.org/10.1038/nature09268

Casciotti, K.L., Trull, T.W., Glover, D.M., Davies, D., 2008. Constraints on nitrogen cycling at the subtropical North Pacific Station ALOHA from isotopic measurements of nitrate and particulate nitrogen. Deep. Res. Part II Top. Stud. Oceanogr. 55, 1661-1672. https://doi.org/10.1016/j.dsr2.2008.04.017

Chavez, F.P., Messié, M., Pennington, J.T., 2011. Marine primary production in relation to Islands. J. Clim. 18, 4796-4813. https://doi.org/10.1175/JCLI3578.1

Clement, A.C., Seager, R., Cane, M.A., 2000. Suppression of El Niño during the Mid-Holocene by changes in the Earth's orbit. Paleoceanography 15, 731-77. https://doi.org/10.1029/1999PA000466

576 Corno, G., Karl, D.M., Church, M.J., Letelier, R.M., Lukas, R., Bidigare, R.R., Abbott, M.R., 
2007. Impact of climate forcing on ecosystem processes in the North Pacific Subtropical Gyre. J. Geophys. Res. 112, 1-14. https://doi.org/10.1029/2006JC003730

Di Lorenzo, E., Schneider, N., Cobb, K.M., Franks, P.J.S., Chhak, K., Miller, J., McWilliams, J.C., Bograd, S.J., Arango, H., Curchitser, E., Powell, T.M., Rivière, P., 2008. North Pacific

Diaz, H.F., Giambelluca, T.W., 2012. Changes in atmospheric circulation patterns associated Gyre Oscillation links ocean climate and ecosystem change. Geophys. Res. Lett. 35, 2-7. https://doi.org/10.1029/2007GL032838 with high and low rainfall regimes in the Hawaiian Islands region on multiple time scales. Glob. Planet. Change 98-99, 97-108. https://doi.org/10.1016/j.gloplacha.2012.08.011

Dore, J.E., Brum, J.R., Tupas, L.M., Karl, D.M., 2002. Seasonal and interannual variability in sources of nitrogen supporting export in the oligotrophic subtropical North Pacific Ocean. Limnol. Oceanogr. 47, 1595-1607. https://doi.org/10.4319/lo.2002.47.6.1595

Ehrlich, H., Etnoyer, P., Litvinov, S.D., Olennikova, M.M., Domaschke, H., Hanke, T., Born, R., Meissner, H., Worch, H., 2006. Biomaterial structure in deep-sea bamboo coral (Anthozoa: Gorgonacea: Isididae): perspectives for the development of bone implants and templates for tissue engineering. $\quad$ Materwiss. Werksttech. 37, 552-557. https://doi.org/10.1002/mawe.200600036

Finkel, Z. V., Beardall, J., Flynn, K.J., Quigg, A., Rees, T.A. V, Raven, J.A., 2010. Phytoplankton in a changing world: Cell size and elemental stoichiometry. J. Plankton Res. 32, 119-137. https://doi.org/10.1093/plankt/fbp098

Galbraith, E.D., Kienast, M., Pedersen, T.F., Calvert, S.E., 2004. Glacial-interglacial modulation of the marine nitrogen cycle by high-latitude $\mathrm{O}_{2}$ supply to the global thermocline. Paleoceanography 19, 1-12. https://doi.org/10.1029/2003PA001000 
600 Guidi, L., Chaffron, S., Bittner, L., Eveillard, D., Larhlimi, A., Roux, S., Darzi, Y., Audic, S., 601 Berline, L., Brum, J.R., Coelho, L.P., Espinoza, J.C.I., Malviya, S., Sunagawa, S., Dimier, 602 C., Kandels-Lewis, S., Picheral, M., Poulain, J., Searson, S., Stemmann, L., Not, F., 603 Hingamp, P., Speich, S., Follows, M., Karp-Boss, L., Boss, E., Ogata, H., Pesant, S., 604 Weissenbach, J., Wincker, P., Acinas, S.G., Bork, P., De Vargas, C., Iudicone, D., Sullivan, 605 M.B., Raes, J., Karsenti, E., Bowler, C., Gorsky, G., 2016. Plankton networks driving 606

608 Guilderson, T.P., McCarthy, M.D., Dunbar, R.B., Englebrecht, A., Roark, E.B., 2013. Late 609 Holocene variations in Pacific surface circulation and biogeochemistry inferred from proteinaceous deep-sea corals. Biogeosciences 10, 6019-6028. https://doi.org/10.5194/bg$10-6019-2013$

Jia, G., Li, Z., 2011. Easterly denitrification signal and nitrogen fixation feedback documented in the western Pacific sediments. Geophys. Res. Lett. 38, L24605, 1-4.

https://doi.org/10.1029/2011GL050021

Karl, D.M., Letelier, R., Hebel, D., Tupas, L., Dore, J., Christian, J., Winn, C., 1995. Ecosystem changes in the North Pacific subtropical gyre attributed to the 1991-92 El Niño. Nature 373,

621 Karl, D.M., 1999. Minireviews: A Sea of Change: Biogeochemical Variability in the North 622 Pacific Subtropical Gyre. Ecosystems 2, 181-214. https://doi.org/10.1007/s100219900068 
623 Karl, D.M., Bidigare, R.R., Letelier, R.M., 2001. Long-term changes in plankton community

624 structure and productivity in the North Pacific Subtropical Gyre: The domain shift

625 hypothesis. Deep Sea Res. Part II Top. Stud. Oceanogr. 48, 1449-1470.

626 https://doi.org/10.1016/S0967-0645(00)00149-1

627 Karl, D.M., Church, M.J., Dore, J.E., Letelier, R.M., Mahaffey, C., 2011. Predictable and

628 efficient carbon sequestration in the North Pacific Ocean supported by symbiotic nitrogen

629 fixation. PNAS 109, 6, 1842-1849. https://doi.org/10.1073/pnas.1120312109

630 Laws, E.A., Popp, B.N., Bidigare, R.R., Kennicutt, M.C., Macko, S.A., 1995. Dependence of

631 phytoplankton carbon isotopic composition on growth rate and $\left[\mathrm{CO}_{2}\right]$ aq: theoretical

632 considerations and experimental results. Geochim. Cosmochim. Acta 59, 1131-1138.

633 https://doi.org/10.1016/0016-7037(95)00030-4

634 Lee, K.E., Slowey, N.C., Herbert, T.D., 2001. Glacial sea surface temperatures in the subtropical

635 North Pacific: A comparison of $\mathrm{Uk}_{37}, \delta^{18} \mathrm{O}$, and foraminiferal assemblage temperature

636 estimates. Paleoceanography 16, 268-279. https://doi.org/10.1029/1999PA000493

637 Lu, Z., Liu, Z., Zhu, J., Cobb, K.M., 2018. A review of paleo El Niño-Southern Oscillation.

638 Atmosphere 9, 4, 130. https://doi.org/10.3390/atmos9040130

639 Martin, J.H., Knauer, G.A., Karl, D.M., Broenkow, W.W., 1987. VERTEX: carbon cycling in

640 the northeast Pacific. Deep Sea Res. Part A, Oceanogr. Res. Pap. 34, 267-285.

$641 \quad$ https://doi.org/10.1016/0198-0149(87)90086-0

642 Massana, R., Logares, R., 2013. Eukaryotic versus prokaryotic marine picoplankton ecology.

643 Environ. Microbiol. 15, 5, 1254-1261. https://doi.org/10.1111/1462-2920.12043

644 McMahon, K.M, McCarthy, M., Sherwood, O., Larsen, T., Guilderson, T., 2015. Millennial645 scale plankton regime shifts in the subtropical North Pacific Ocean. Science 350, 1530- 
McMahon, K.M., Williams, B., Guilderson, T. P., Glynn, D.S., and McCarthy, M.D., 2017. Calibrating amino acid $\delta^{13} \mathrm{C}$ and $\delta^{15} \mathrm{~N}$ offsets between polyp and protein skeleton to develop deep-sea proteinaceous corals as paleoceanographic archives. Geochimica et Cosmochimica, 220, 261-27. https://doi.org/10.1016/j.gca.2017.09.048

Monnin, E., Steig, E.J., Siegenthaler, U., Kawamura, K., Schwander, J., Stauffer, B., Stocker, T.F., Morse, D.L., Barnola, J.M., Bellier, B., Raynaud, D., Fischer, H., 2004. Evidence for

Moy, C.M., Seltzer, G.O., Rodbell, D.T., Anderson, D.M., 2002. Variability of El Niño Southern Oscillation activity at millennial timescales during the Holocene epoch. Nature 420, 162-

Pei, Q., Zhang, D.D., Li, J., Lee, H.F., 2017. Proxy-based Northern Hemisphere temperature reconstruction for the Mid-to-Late Holocene. Theor. Appl. Climatol. 130, 1043-1053.

Polovina, J.J., Howell, E. a., Abecassis, M., 2008. Ocean's least productive waters are https://doi.org/10.1007/s00704-016-1932-5 expanding. Geophys. Res. Lett. 35, 2-6. https://doi.org/10.1029/2007GL031745

Popp, B.N., Laws, E. a., Bidigare, R.R., Dore, J.E., Hanson, K.L., Wakeham, S.G., 1998. Effect

667 Quay, P., Stutsman, J., 2003. Surface layer carbon budget for the subtropical N. Pacific: $\delta^{13} \mathrm{C}$ 668 constraints at station ALOHA. Deep. Res. Part I Oceanogr. Res. Pap. 50, 1045-1061. 
670 Rau, G.H., Takahashi, T., Des Marais, D.J., 1989. Latitudinal variations in plankton $\delta^{13}$ C:

671 implications for $\mathrm{CO}_{2}$ and productivity in past oceans. Nature 341, 516-518.

672 https://doi.org/10.1038/341516a0

673 Rau, G.H., Riebesell, U., Wolf-Gladrow, D., 1996. A model of photosynthetic ${ }^{13}$ C fractionation 674 by marine phytoplankton based on diffusive molecular $\mathrm{CO}_{2}$ uptake. Mar. Ecol. Prog. Ser.

675 133, 275-285. https://doi.org/10.3354/meps133275

Reimer, P.J., Bard, E., Bayliss, A., Beck, J.W., Blackwell, P.G., Ramsey, C.B., Buck, C.E., Cheng, H., Edwards, R.L., Friedrich, M., Grootes, P.M., Guilderson, T.P., Haflidason, H., Hajdas, I., Hatté, C., Heaton, T.J., Hoffmann, D.L., Hogg, A.G., Hughen, K.A., Kaiser, K.F., Kromer, B., Manning, S.W., Niu, M., Reimer, R.W., Richards, D.A., Scott, E.M., Southon, J.R., Staff, R.A., Turney, C.S.M., van der Plicht, J., 2013. IntCal13 and Marine13 Radiocarbon Age Calibration Curves 0-50,000 Years cal BP. Radiocarbon 55, 1869-1887. https://doi.org/10.2458/azu_js_rc.55.16947

Roark, E.B., Guilderson, T.P., Dunbar, R.B., Fallon, S.J., Mucciarone, D. A., 2009. Extreme longevity in proteinaceous deep-sea corals. Proc. Natl. Acad. Sci. U. S. A. 106, 5204-5208. https://doi.org/10.1073/pnas.0810875106

Rodionov, S.N., 2004. A sequential algorithm for testing climate regime shifts. Geophys. Res. Lett. 31. https://doi.org/10.1029/2004GL019448. Regime shift program available at: https://www.beringclimate.noaa.gov/regimes/

Schiff, J.T., Batista, F.C., Sherwood, O.A., Guilderson, T.P., Hill, T.M., Ravelo, A.C., McMahon, K.W., Mccarthy, M.D., 2014. Compound specific amino acid $\delta^{13} \mathrm{C}$ patterns in a deep-sea proteinaceous coral: Implications for reconstructing detailed $\delta^{13} \mathrm{C}$ records of 
exported primary production. Mar. Chem. 166, 82-91. https://doi.org/10.1016/j.marchem.2014.09.008

694 Schneider, T., Bischoff, T., Haug, G.H., 2014. Migrations and dynamics of the intertropical convergence zone. Nature 513, 45-53. https://doi.org/10.1038/nature13636

Scott, K.M., Henn-Sax, M., Harmer, T.L., Longo, D.L., Frame, C.H., Cavanaugh, C.M., 2007.

Sherwood, O. A., Scott, D.B., Risk, M.J., 2006. Late Holocene radiocarbon and aspartic acid racemization dating of deep-sea octocorals. Geochim. Cosmochim. Acta 70, 2806-2814.

Sherwood, O. A., Guilderson, T.P., Batista, F.C., Schiff, J.T., McCarthy, M.D., 2014. Increasing subtropical North Pacific Ocean nitrogen fixation since the Little Ice Age. Nature 505, 7881. https://doi.org/10.1038/nature12784

Sigman, D.M., DiFiore, P.J., Hain, M.P., Deutsch, C., Karl, D.M., Bo, V., 2009. Sinking organic matter spreads the nitrogen isotope signal of pelagic denitrification in the North Pacific.

Young, J.N., Bruggeman, J., Rickaby, R.E.M., Erez, J., Conte, M., 2013. Evidence for changes Geophysical Research Letters 36, L08605, 1-5. https://doi.org/10.1029/2008GL035784

Tesdal, J.E., Galbraith, E.D., Kienast, M., 2013. Nitrogen isotopes in bulk marine sediment: Linking seafloor observations with subseafloor records. Biogeosciences 10, 101-118. in carbon isotopic fractionation by phytoplankton between 1960 and 2010. Global Biogeochem. Cycles 27, 505-515. https://doi.org/10.1002/gbc.20045 
715 Zubkov, M. V., 2014. Faster growth of the major prokaryotic versus eukaryotic $\mathrm{CO}_{2}$ fixers in the

716 oligotrophic ocean. Nat. Commun. 5, 1-6. https://doi.org/10.1038/ncomms4776 
Figure 1. Study Location. A) SeaWIFS ocean color globe of chlorophyll during boreal summer with Hawai'ian Islands squared in red. B) An annual SST $\left({ }^{\circ} \mathrm{C}\right)$ map of Hawaii using World Ocean Atlas 19552015 annual data, with arrows pointing to the two coral collection locations on the eastern side of Oahu Island; L for Lanikai (this study), M for Makapu'u (Sherwood et al., 2014), and two sediment core locations P17 and P20 from Lee et al. 2001. Also shown is Station ALOHA from the HOTS program (open circle).
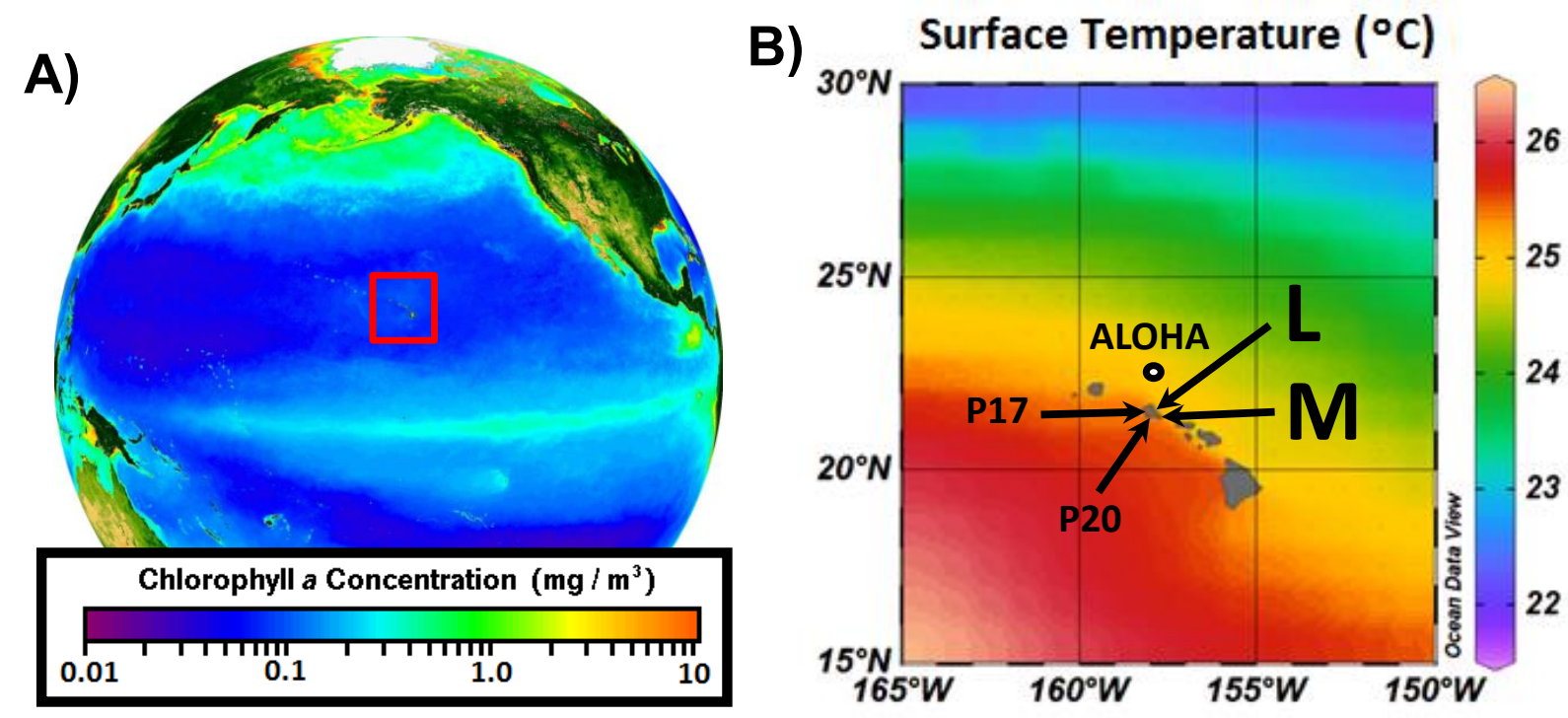
Figure 2. Late Holocene bulk coral $\delta^{15} \mathrm{~N}$ records compared with selected climactic and sedimentary $\delta^{15} \mathbf{N}$ records. A) Three new bulk coral $\delta^{15} \mathrm{~N}$ records from Lanikai (colors indicate coral; see legend); blue shading indicates previously published records (Makapu'u) from the same region. B) Mid-month insolation $15^{\circ} \mathrm{N}$ for July which is primarily driven by changes in solar precession cycles (Berger and Loutre, 1991). Also shaded are major ENSO periods where most proxy records agree (Lu et al. 2018). C) Data from bulk $\delta^{15} \mathrm{~N}$ sediment records from the North East Pacific binned by $250 \mathrm{yr}$ time steps from 3 records from offshore Mexico $\left(22\right.$ to $\left.23^{\circ} \mathrm{N}\right), 5$ off Central America $\left(7\right.$ to $\left.16^{\circ} \mathrm{N}\right)$, and 4 in the Eastern Tropical Pacific (ETP, 0 to $\left.1^{\circ} \mathrm{N}\right)$. Data from the NICOPP database from Tesdal et al. 2013; see supplemental file for more information. Error bars indicate standard deviation.

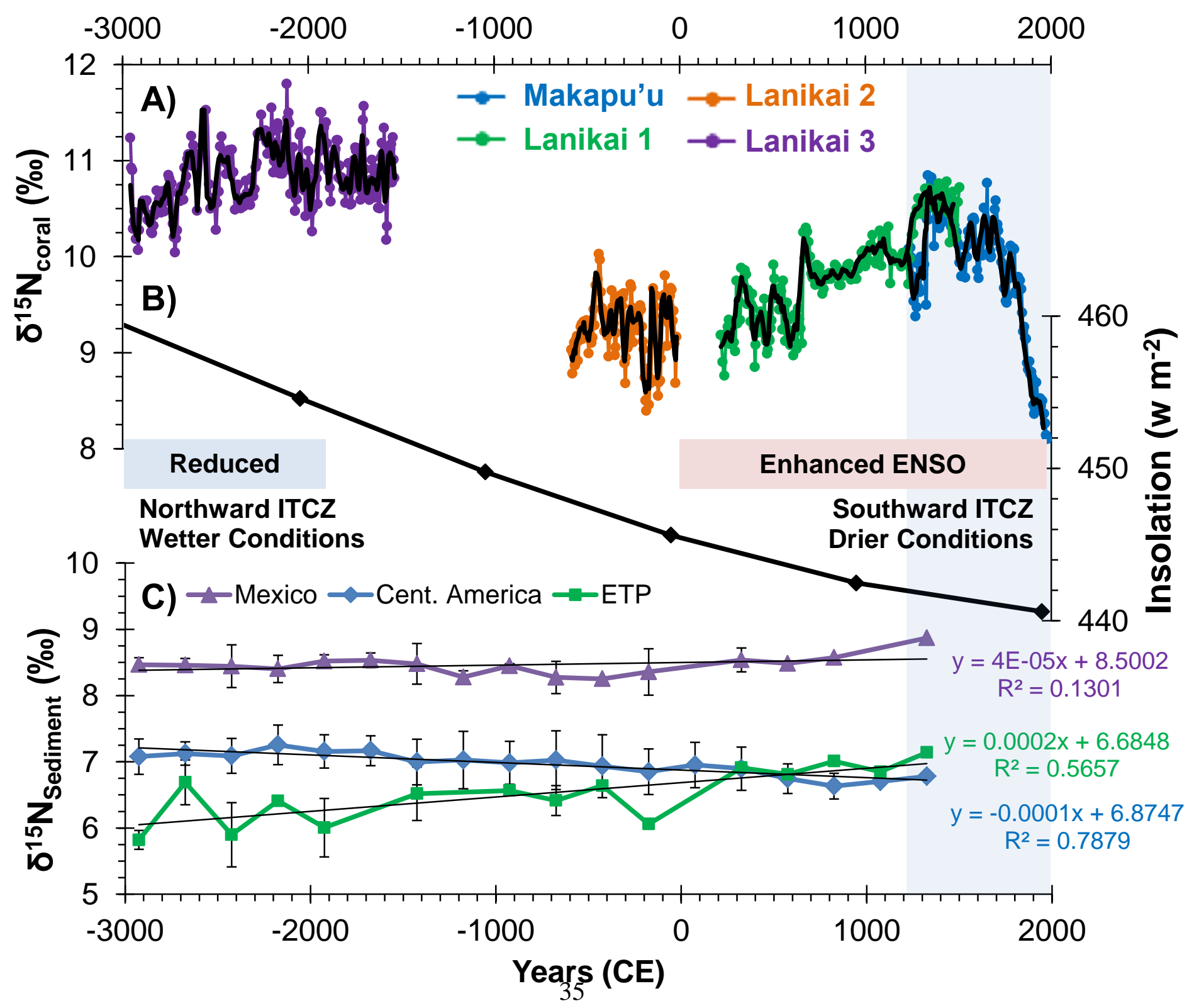


Figure 3. Late Holocene bulk coral $\delta^{13} \mathrm{C}$ records compared with selected climactic data, sedimentary and atmospheric $\delta^{13} \mathbf{C}$ records. A) Bulk coral carbon isotope record, with blue shading depicting extent of previous coral records from the region, black lines representing a 5 point moving average. B) Alkenone SST records for the 2 sediment cores (P17, P20) collected near Oahu, Hawaii (Lee et al. 2001) believed to be representative of wintertime SST conditions in the NPSG. C) Atmospheric $\mathrm{CO}_{2}$ concentration from Antarctic ice core records (Monnin et al. 2004). D) Red sediment color intensity record (grey), interpreted to be driven by El Nino Southern Oscillation with the black line designating a 20 year moving average (Moy et al. 2003).

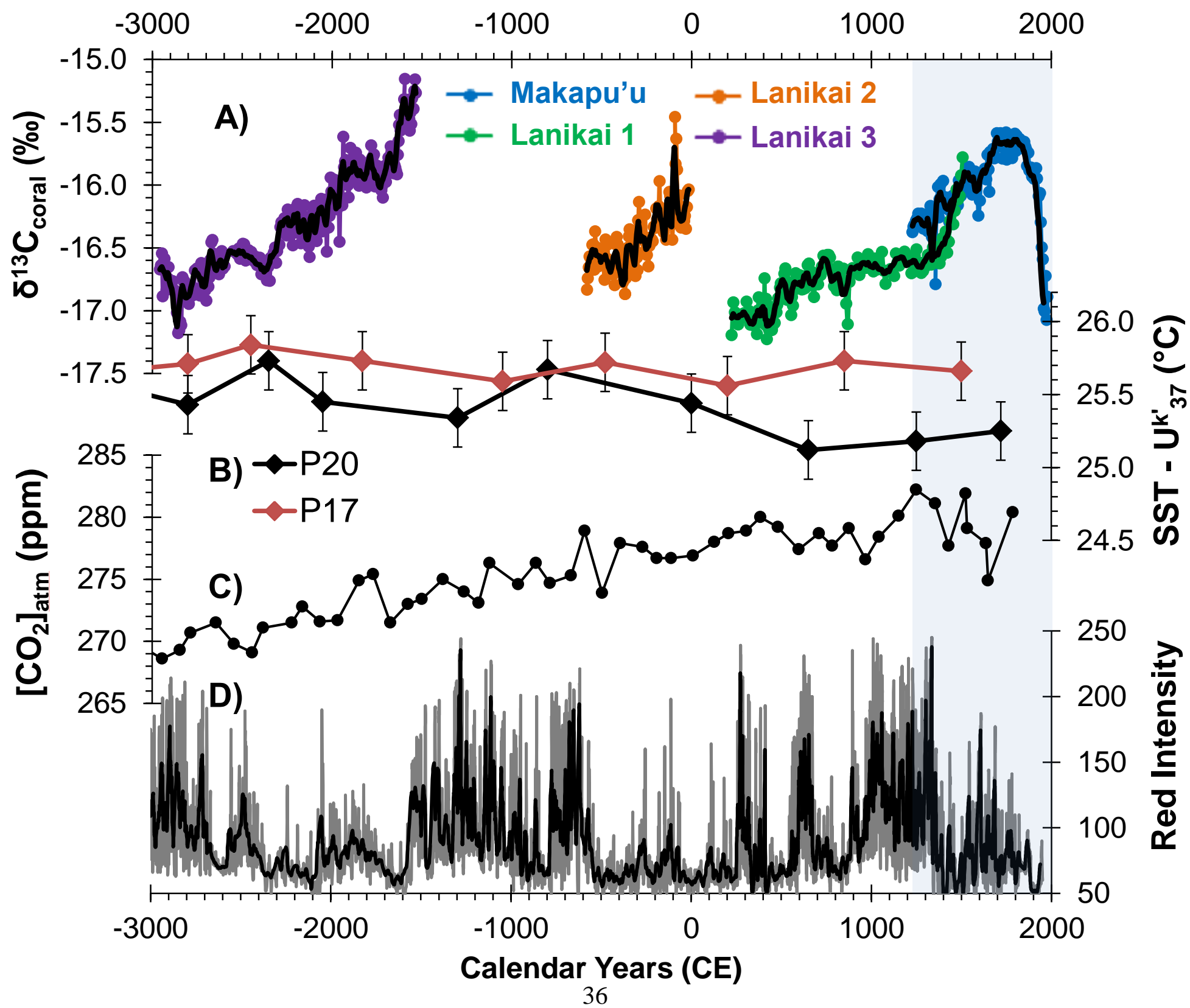


Figure 4. Coupled vs. decoupled changes in $\delta^{15} \mathrm{~N}$ and $\delta^{13} \mathrm{C}$ bulk isotope values of export production in NPSG through the Late-Holocene. Bulk nitrogen and carbon isotopic records from $K$. haumeaae (A and B; as presented in prior figures) are overlain to indicate distinct periods of coupling vs. decoupling in isotopic change. Unshaded periods indicates where $\delta^{15} \mathrm{~N}$ and $\delta^{13} \mathrm{C}$ are decoupled (DC1, DC2), while red shading indicates coupling as the isotope systems trend in the same direction $(\mathrm{C} 1, \mathrm{C} 2, \mathrm{C} 3)$. Grey dashed arrows indicate the assumed trend in isotope values during discontinuities in our current records while black lines designate the 5 point moving average.

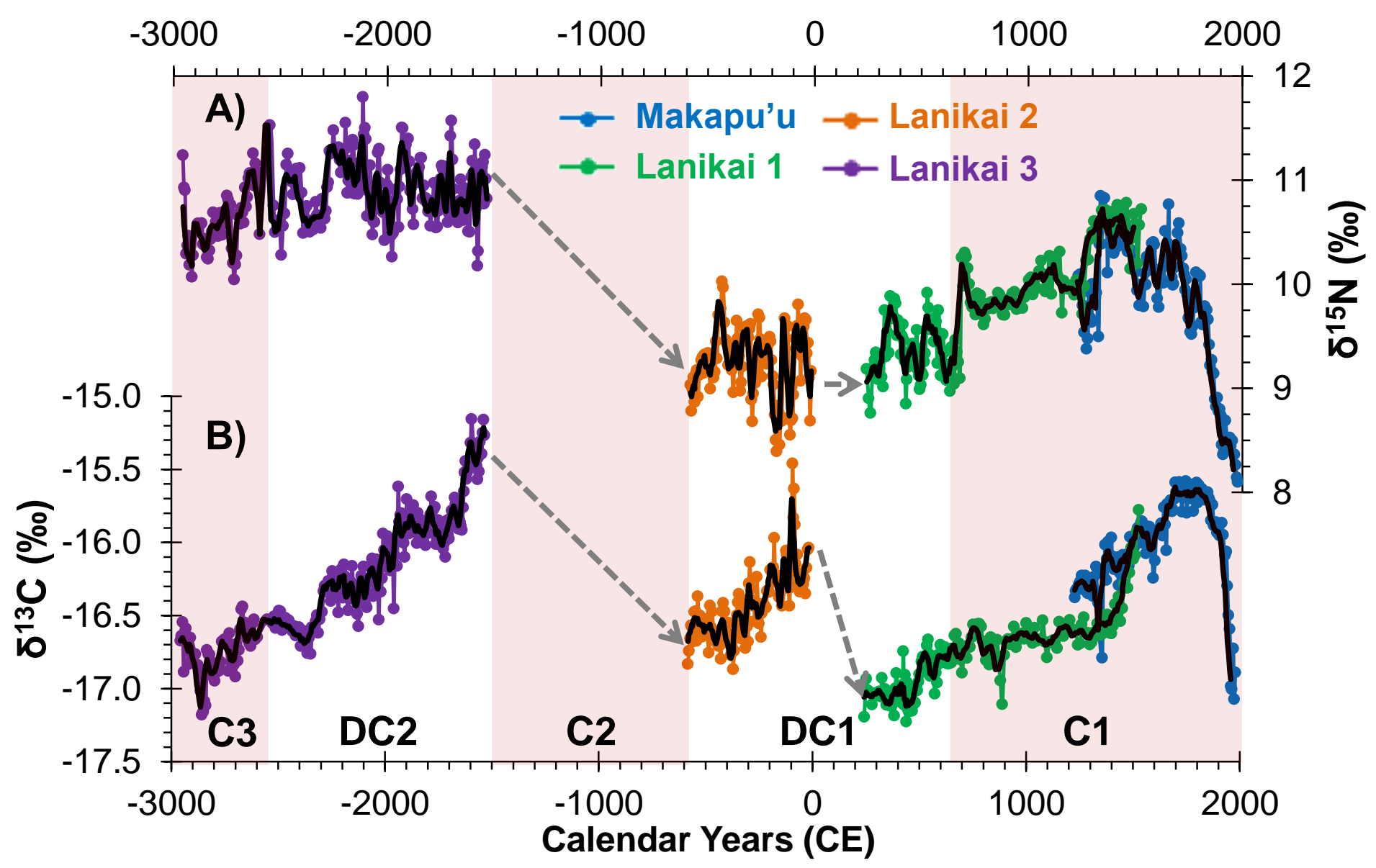


Figure S1. Radiocarbon age models. Age-models were determined for each specimen using a Bayesian modeling approach, Bacon (Blaauw and Christensen 2011) using Marine13 (Reimer et al., 2013) and a reservoir age correction (expressed as $\Delta \mathrm{R}$ ) of -28 \pm 4 (Druffel et al., 2001). Blueshaded areas represent the conventional calibrated ${ }^{14} \mathrm{C}$ age distributions. Dark grey lines represent all iterations $(n=10,000)$ of the model, while the fine red line is based on the weighted mean age for each depth which was used in this study. Lanikai 1 age model was calculated using an accumulation rate of $10 \mathrm{yrs} / 0.1 \mathrm{~mm}$ while Lanikai 2 and 3 used an accumulation rate of 5 yrs/0.1 mm. All corals used an accumulation shape of 1.5 , memory strength 4 , and a mean memory of 0.7 . The grey stippled lines show the $95 \%$ confidence intervals which averaged 98 \pm 15 years. The shape of the curves reflects variable growth rates in the four coral samples illustrated. A, B, C) Lanikai corals used in this study with original collection names also listed.
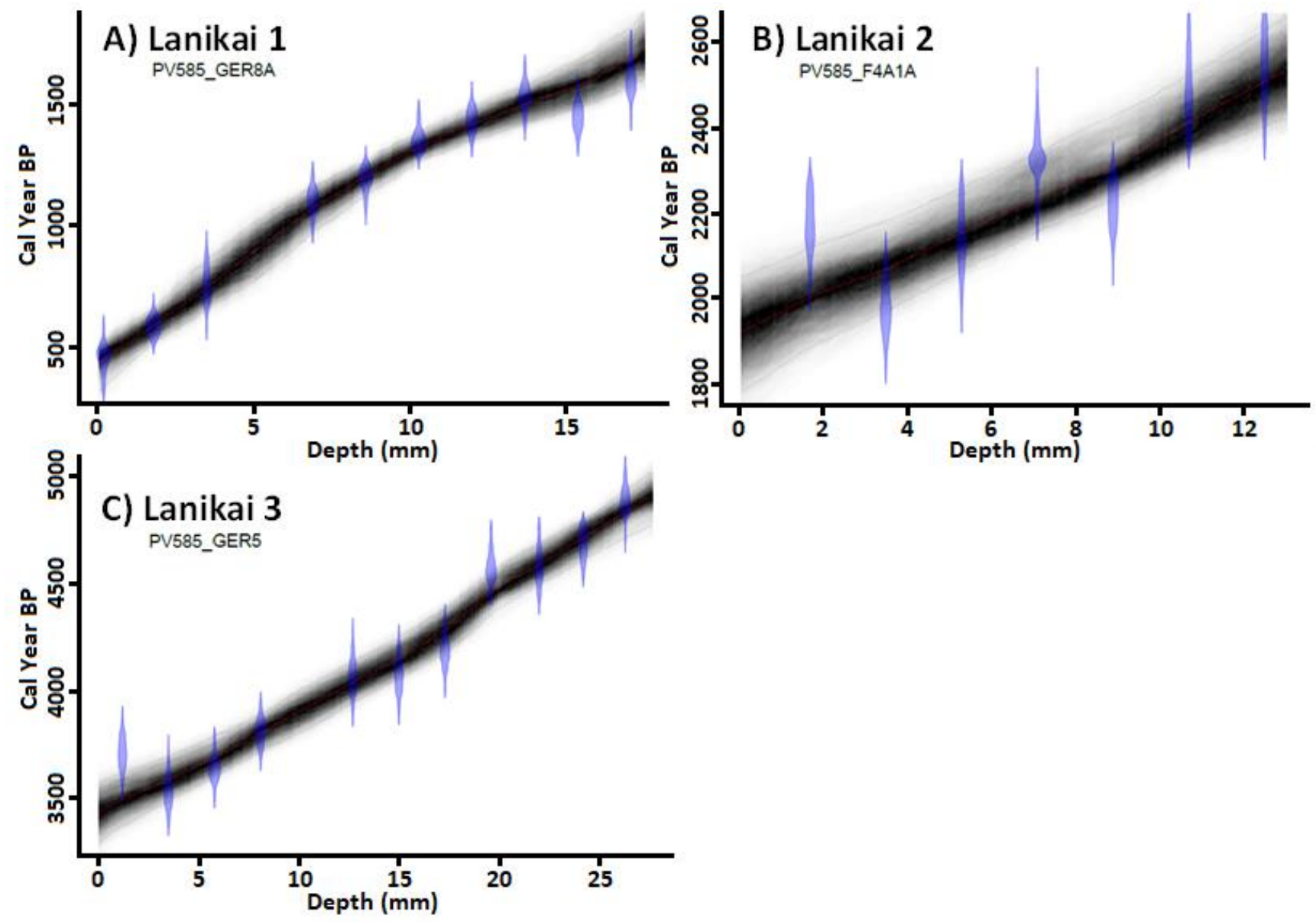
Figure S2. Regime shift detection. A\&D) Bulk coral $\delta^{15} \mathrm{~N}$ and $\delta^{13} \mathrm{C}$ records from Lanikai (colors same as previous figures). Black lines signify regimes detected by software designed to automatically detect statistically significant shifts in the mean level and the magnitude of fluctuations in time series using sequential t-tests (Rodionov 2004). B\&E) $\delta^{15} \mathrm{~N}$ and $\delta^{13} \mathrm{C}$ residuals after the stepwise regime function is removed. C\&F) Weight attributed to outliers (using Huber's weight function, weight $=\min (1$, parameter $/(\mid$ anomaly $\mid))$, where the anomaly is the deviation from the expected mean value of the new regime normalized by the standard deviation averaged for all consecutive sections of the cut-off length in the series (http://www.beringclimate.noaa.gov/regimes/help.html). If anomalies are less than or equal to the value of the parameter then their weights are equal to one. Otherwise, the weights are inversely proportional to the distance from the expected mean value of the new regime. 

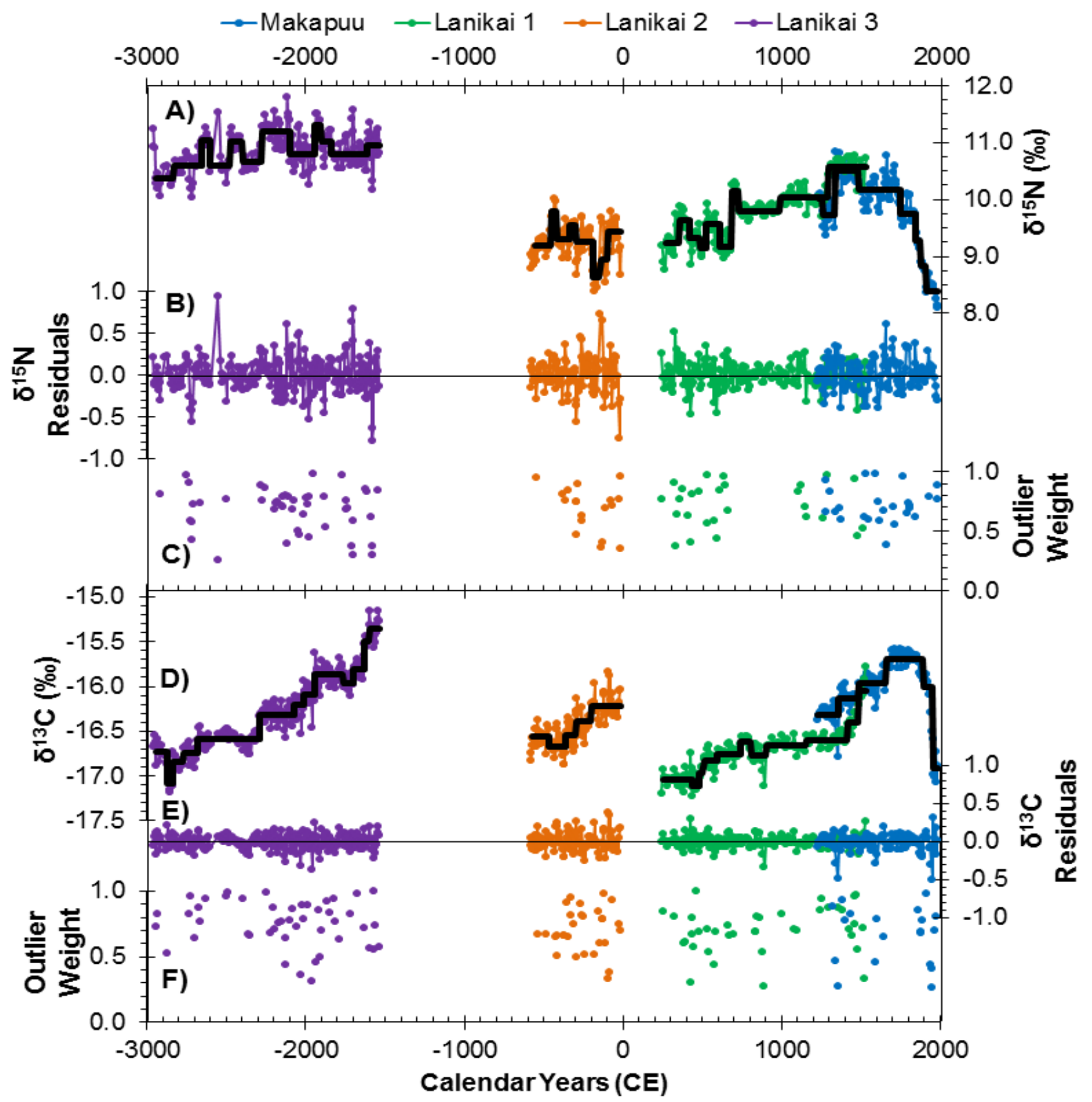
Figure S3. Map of sediment core locations and regional sections. West Pacific (yellow) includes seven sediment $\delta^{15} \mathrm{~N}$ records published in Kienast et al. (2008), Jia and Li (2011), Langton et al. (2008)*, Rafter and Charles (2012). North West Pacific (red) includes four records published in Kao et al. (2008)*, Kienast (2000). North East Pacific (blue) includes nine records published in Hendy et al (2004)*, McKay et al (2004)*, Chang et al. (2008)*, Emmer and Thunell (2000)*, Kienast et al. (2002), Ganeshram et al. (1995*, 2000*), Arellano-Torres (2010)*. East Pacific (green) includes ten records published in Dubois et al. (2011), Pichevin et al. (2009, 2010), Thunell and Kepple (2004)*, Hendy and Pedersen (2006)*, and Robinson et al. (2009). References marked with a * indicates records using updated age-models. Sedimentary age models were updated using the CALIB program (Stuiver et al. 2017) and Marine13 (Reimer et al., 2013), while retaining reservoir age corrections from the original studies before using a piecewise linear regression to form an updated age model.

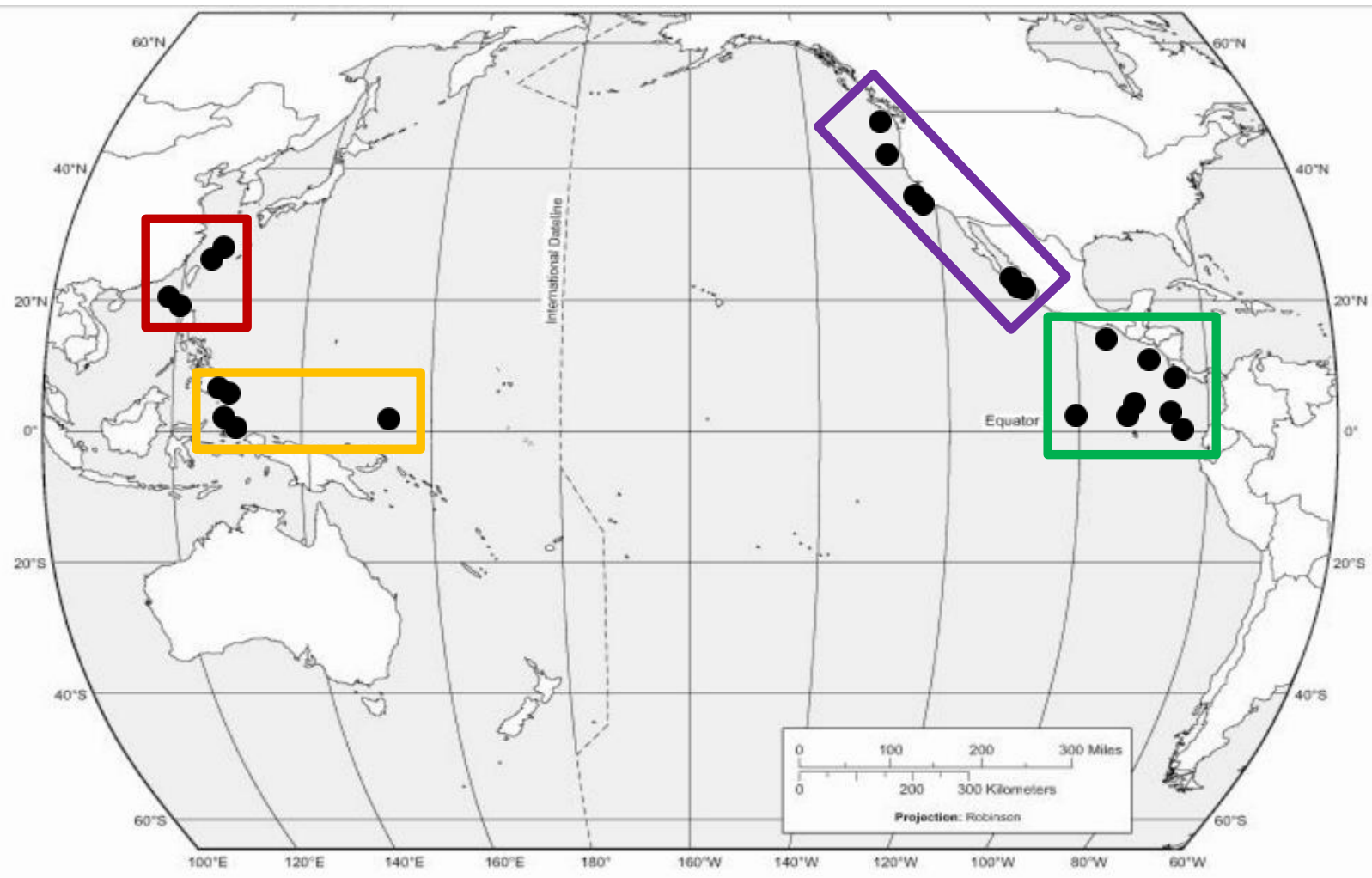


Figure S4. Linear regressions of sedimentary and coral $\delta^{15} \mathbf{N}$ records. Sediment data limited to the last 6000 years ( -4000 to $2000 \mathrm{CE})$ and records with >2 points within this period $(\mathrm{n}=30$; see methods). Regions correspond to Fig. S3. Data was standardized to a mean of zero for the 6000 years in order to remove site specific variability in absolute values (e.g. depth differences). Black line designates the overall linear trend of North Pacific sediment $\delta^{15} \mathrm{~N}$ over 6000 years.

- East Pacific $\quad \Delta$ NE Pacific $\quad$ NW Pacific $\diamond$ West Pacific

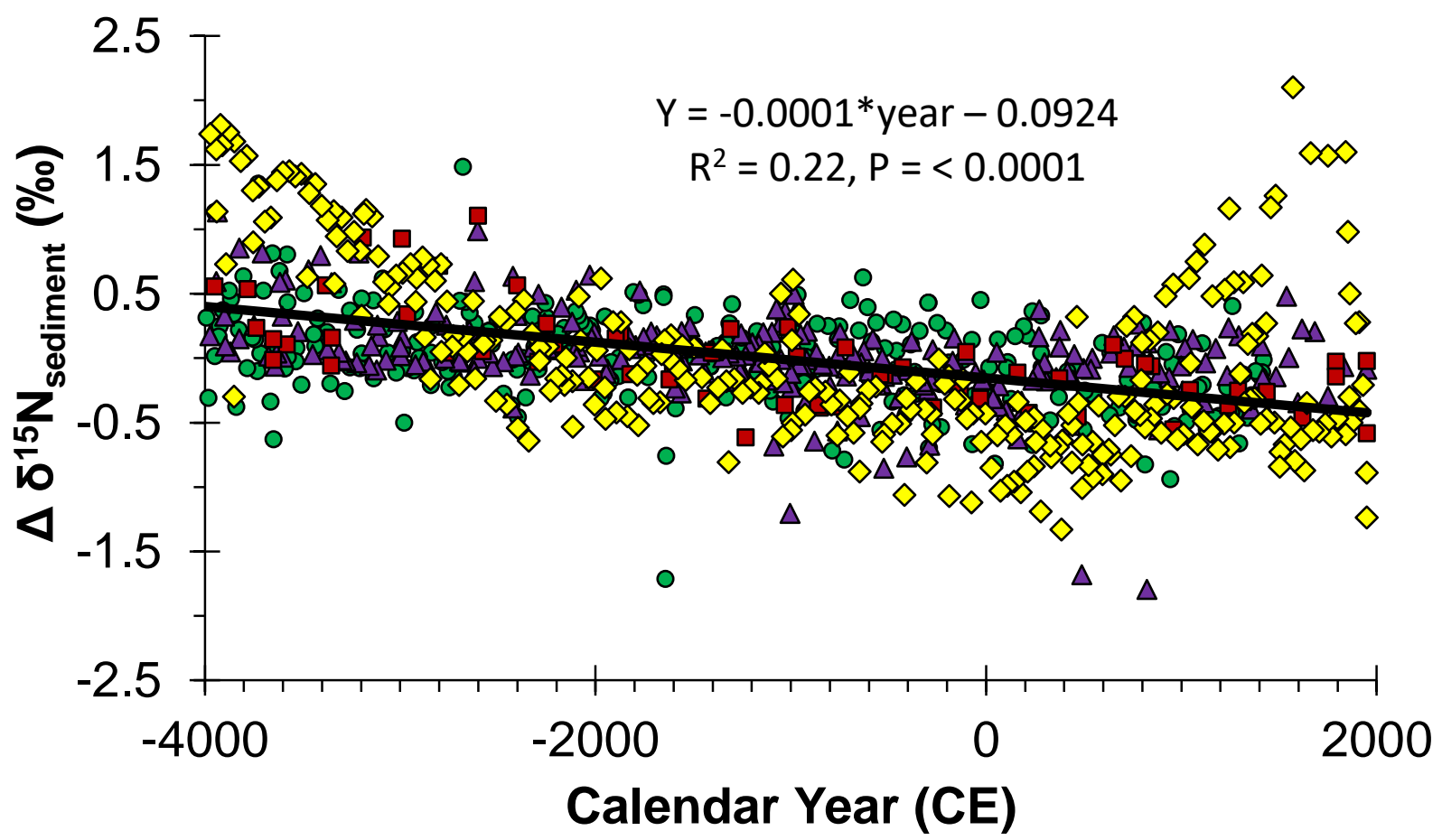


Supplemental Data Table $1 \mid K$. haumeaae radiocarbon data. All analysis performed at Lawrence Livermore National Laboratory, following previously established radiocarbon methods for proteinaceous deep-sea corals (Roark et al., 2009, Guilderson et al. 2013). Briefly, this involves converting acid-pretreated coral samples to $\mathrm{CO}_{2}$ via sealed tube combustion before being reduced to graphite in the presence of an iron catalyst and hydrogen gas (Vogel et al., 1987). Results are reported as Fraction Modern, including both a background and $\delta^{13} \mathrm{C}$ correction (cf. Reimer et al., 2004), and as conventional radiocarbon years as per Stuiver and Polach, 1977. A constant $\Delta \mathrm{R}$ of $-28 \pm 4$ (Druffel et al., 2001) was used for age modeling.

\begin{tabular}{|c|c|c|c|c|c|c|c|c|c|c|c|}
\hline Coral & $\begin{array}{c}\text { CAMS } \\
\text { ID }\end{array}$ & ID \# & $\begin{array}{c}\text { Distance } \\
(\mathbf{m m})\end{array}$ & $\begin{array}{l}\delta^{13} \mathrm{C} \\
(\% 0)\end{array}$ & $\begin{array}{l}\text { Fraction } \\
\text { Modern }\end{array}$ & error & $\begin{array}{r}{ }^{14} \mathrm{C} \\
\text { age }\end{array}$ & error & $\begin{array}{c}\text { Model } \\
\text { Age } \\
\text { (yr BP) }\end{array}$ & $\begin{array}{c}95 \% \\
\text { Confidence } \\
\text { interval }\end{array}$ & $\begin{array}{c}\text { Model } \\
\text { Age } \\
\text { (yr CE) }\end{array}$ \\
\hline \multirow[t]{2}{*}{ Lanikai 1} & 166951 & 2 & 0.2 & -15.92 & 0.9046 & 0.0055 & 805 & 50 & 451 & 97 & 1499 \\
\hline & 166952 & 18 & 1.8 & -16.49 & 0.8859 & 0.0040 & 975 & 40 & 589 & 69 & 1361 \\
\hline (PV585 & 166953 & 35 & 3.5 & -16.60 & 0.8647 & 0.0066 & 1170 & 70 & 747 & 100 & 1203 \\
\hline \multirow[t]{7}{*}{ Ger8) } & 166955 & 69 & 6.9 & -16.77 & 0.8278 & 0.0032 & 1520 & 35 & 1072 & 90 & 878 \\
\hline & 166956 & 86 & 8.6 & -16.60 & 0.8191 & 0.0035 & 1605 & 35 & 1203 & 72 & 747 \\
\hline & 166957 & 103 & 10.3 & -16.73 & 0.8006 & 0.0028 & 1785 & 30 & 1325 & 59 & 625 \\
\hline & 166958 & 120 & 12 & -16.92 & 0.7932 & 0.0028 & 1860 & 30 & 1419 & 69 & 531 \\
\hline & 166959 & 137 & 13.7 & -17.15 & 0.7846 & 0.0027 & 1950 & 30 & 1503 & 79 & 447 \\
\hline & 166960 & 154 & 15.4 & -17.00 & 0.7918 & 0.0031 & 1875 & 35 & 1582 & 98 & 368 \\
\hline & 166961 & 171 & 17.1 & -17.11 & 0.7793 & 0.0037 & 2005 & 40 & 1691 & 123 & 259 \\
\hline \multirow[t]{7}{*}{ Lanikai 2} & 166962 & 17 & 1.7 & -16.22 & 0.7347 & 0.0031 & 2475 & 35 & 2001 & 117 & -51 \\
\hline & 166963 & 35 & 3.5 & -16.09 & 0.7488 & 0.0028 & 2325 & 35 & 2069 & 106 & -119 \\
\hline & 166964 & 53 & 5.3 & -16.34 & 0.7370 & 0.0033 & 2450 & 40 & 2152 & 97 & -202 \\
\hline & 166965 & 71 & 7.1 & -16.32 & 0.7220 & 0.0024 & 2615 & 30 & 2239 & 93 & -289 \\
\hline & 166966 & 89 & 8.9 & -16.64 & 0.7304 & 0.0031 & 2525 & 35 & 2312 & 96 & -362 \\
\hline & 166967 & 107 & 10.7 & -16.63 & 0.7122 & 0.0028 & 2725 & 35 & 2413 & 94 & -463 \\
\hline & 166968 & 125 & 12.5 & -16.68 & 0.7090 & 0.0033 & 2765 & 40 & 2507 & 112 & -557 \\
\hline \multirow[t]{11}{*}{ Lanikai 3} & 168323 & 12 & 1.2 & -15.16 & 0.6276 & 0.0034 & 3740 & 45 & 3489 & 124 & -1539 \\
\hline & 168324 & 35 & 3.5 & -15.65 & 0.6392 & 0.0036 & 3595 & 50 & 3581 & 104 & -1631 \\
\hline & 168325 & 58 & 5.8 & -16.03 & 0.6322 & 0.0023 & 3685 & 30 & 3682 & 94 & -1732 \\
\hline & 168326 & 81 & 8.1 & -16.01 & 0.6212 & 0.0023 & 3825 & 30 & 3801 & 89 & -1851 \\
\hline & 168327 & 127 & 12.7 & -16.45 & 0.6068 & 0.0031 & 4015 & 45 & 4036 & 96 & -2086 \\
\hline & 168328 & 150 & 15 & -16.38 & 0.6067 & 0.0029 & 4015 & 40 & 4147 & 97 & -2197 \\
\hline & 168329 & 173 & 17.3 & -16.59 & 0.6005 & 0.0024 & 4095 & 35 & 4280 & 102 & -2330 \\
\hline & 168330 & 196 & 19.6 & -16.58 & 0.5798 & 0.0021 & 4380 & 30 & 4455 & 100 & -2505 \\
\hline & 168331 & 220 & 22 & -16.67 & 0.5796 & 0.0029 & 4380 & 45 & 4589 & 96 & -2639 \\
\hline & 168332 & 242 & 24.2 & -16.68 & 0.5739 & 0.0022 & 4460 & 35 & 4713 & 95 & -2763 \\
\hline & 168333 & 263 & 26.3 & -16.77 & 0.5621 & 0.0029 & 4630 & 45 & 4837 & 109 & -2887 \\
\hline
\end{tabular}


Supplemental Data Table $2 \mid K$. haumeaae $\delta^{13} \mathrm{C}$ and $\delta^{15} \mathrm{~N}$ bulk data and C:N ratios. All

analysis performed at the Stable Isotope Lab of the University of California Santa Cruz using

VPDB and $\mathrm{N}_{2}$ air as standards for $\delta^{13} \mathrm{C}$ and $\delta^{15} \mathrm{~N}$ respectively. Any samples with an identification

ending in "D" are duplicate analyses. Samples with a * symbol in ID were excluded from

analysis due to an abnormal C:N ratio (below 2.7 or above 3.1 ) and/or an estimated mass of

under $20 \mu \mathrm{g} \mathrm{N}$ (which approaches the limit of detection for $\delta^{15} \mathrm{~N}$ on an EA-IRMS).

\begin{tabular}{|c|c|c|c|c|c|c|c|c|c|c|c|c|c|}
\hline ID & $\begin{array}{c}\text { depth } \\
(\mathbf{m m})\end{array}$ & $\begin{array}{l}\text { Year } \\
(\mathrm{CE})\end{array}$ & $\begin{array}{c}95 \% \\
\text { CI } \\
\text { (yrs) }\end{array}$ & $\begin{array}{c}\delta^{13} \mathrm{C} \\
(\% 0)\end{array}$ & $\begin{array}{c}\delta^{15} \mathbf{N} \\
(\%)\end{array}$ & $\begin{array}{c}\text { C:N } \\
\text { Ratio }\end{array}$ & ID & $\begin{array}{l}\text { depth } \\
(\mathbf{m m})\end{array}$ & $\begin{array}{l}\text { Year } \\
\text { (CE) }\end{array}$ & $\begin{array}{c}95 \% \\
\text { CI } \\
\text { (yrs) }\end{array}$ & $\begin{array}{l}\delta^{13} \mathrm{C} \\
(\%)\end{array}$ & $\begin{array}{c}\delta^{15} \mathbf{N} \\
(\% 0)\end{array}$ & $\begin{array}{c}\text { C:N } \\
\text { Ratio }\end{array}$ \\
\hline L1_1 & 0.1 & 1508 & 101 & -15.78 & 10.72 & 3.07 & L3_1* & 0.1 & -1483 & 139 & -15.88 & 11.85 & 3.62 \\
\hline L1_2 & 0.2 & 1499 & 97 & -15.92 & 10.57 & 3.03 & L3_2* & 0.2 & -1489 & 137 & -15.13 & 12.19 & 3.26 \\
\hline L1_3 & 0.3 & 1490 & 93 & -16.09 & 10.20 & 3.14 & L3_3* & 0.3 & -1494 & 135 & -14.94 & 12.04 & 3.13 \\
\hline L1_4 & 0.4 & 1481 & 91 & -16.12 & 10.58 & 3.00 & L3_4* & 0.4 & -1499 & 133 & -15.05 & 12.08 & 3.06 \\
\hline L1_5 & 0.5 & 1473 & 92 & -16.04 & 10.67 & 2.95 & L3_5* & 0.5 & -1504 & 132 & -15.15 & 11.92 & 3.05 \\
\hline L1_6 & 0.6 & 1464 & 95 & -16.21 & 10.44 & 3.02 & L3_6* & 0.6 & -1510 & 132 & -14.86 & 11.25 & 3.03 \\
\hline L1_7* & 0.7 & 1456 & 91 & -16.31 & 10.15 & 3.11 & L3_6D* & 0.6 & -1510 & 132 & -16.39 & 10.57 & 2.86 \\
\hline L1_8 & 0.8 & 1447 & 87 & -16.31 & 10.46 & 2.98 & L3_7* & 0.7 & -1515 & 130 & -14.93 & 10.97 & 3.07 \\
\hline L1_9 & 0.9 & 1439 & 84 & -16.28 & 10.78 & 2.96 & L3_8* & 0.8 & -1520 & 128 & -15.02 & 11.22 & 3.07 \\
\hline L1_10 & 1.0 & 1430 & 85 & -16.43 & 10.56 & 3.08 & L3_9* & 0.9 & -1525 & 127 & -15.07 & 11.10 & 3.00 \\
\hline L1_10D & 1.0 & 1430 & 85 & -16.47 & 10.66 & 2.88 & L3_10* & 1.0 & -1530 & 126 & -15.13 & 10.80 & 3.03 \\
\hline L1_11 & 1.1 & 1421 & 87 & -16.54 & 10.54 & 3.10 & L3_11 & 1.1 & -1535 & 125 & -15.27 & 10.82 & 3.04 \\
\hline L1_12 & 1.2 & 1413 & 81 & -16.37 & 10.75 & 2.94 & L3_12 & 1.2 & -1539 & 124 & -15.16 & 11.01 & 3.02 \\
\hline L1_13 & 1.3 & 1404 & 77 & -16.53 & 10.52 & 3.05 & L3_13 & 1.3 & -1543 & 123 & -15.25 & 11.24 & 2.99 \\
\hline L1_14 & 1.4 & 1396 & 74 & -16.42 & 10.76 & 2.97 & L3_14 & 1.4 & -1548 & 123 & -15.40 & 10.77 & 3.01 \\
\hline L1_15 & 1.5 & 1388 & 73 & -16.57 & 10.57 & 3.03 & L3_15 & 1.5 & -1552 & 122 & -15.40 & 11.17 & 2.95 \\
\hline L1_16 & 1.6 & 1379 & 74 & -16.62 & 10.49 & 3.03 & L3_16 & 1.6 & -1556 & 123 & -15.31 & 11.12 & 3.00 \\
\hline L1_17 & 1.7 & 1370 & 71 & -16.62 & 10.52 & 3.04 & L3_17 & 1.7 & -1560 & 121 & -15.52 & 11.11 & 3.02 \\
\hline L1_18 & 1.8 & 1361 & 69 & -16.49 & 10.69 & 3.00 & L3_18 & 1.8 & -1564 & 120 & -15.42 & 10.91 & 2.96 \\
\hline L1_19 & 1.9 & 1351 & 70 & -16.53 & 10.56 & 3.03 & L3_19 & 1.9 & -1568 & 119 & -15.57 & 10.98 & 2.98 \\
\hline L1_20 & 2.0 & 1342 & 74 & -16.50 & 10.71 & 2.95 & L3_20 & 2.0 & -1572 & 118 & -15.48 & 10.78 & 2.95 \\
\hline L1_21 & 2.1 & 1332 & 80 & -16.63 & 10.68 & 3.04 & L3_21 & 2.1 & -1576 & 118 & -15.36 & 10.32 & 2.96 \\
\hline L1_22 & 2.2 & 1323 & 80 & -16.59 & 10.71 & 2.96 & L3_22 & 2.2 & -1579 & 116 & -15.35 & 10.17 & 2.96 \\
\hline L1_23 & 2.3 & 1314 & 81 & -16.56 & 10.61 & 2.94 & L3_23 & 2.3 & -1584 & 115 & -15.45 & 10.74 & 2.97 \\
\hline L1_24 & 2.4 & 1305 & 84 & -16.64 & 10.44 & 2.99 & L3_24 & 2.4 & -1587 & 114 & -15.32 & 10.86 & 2.95 \\
\hline L1_25 & 2.5 & 1295 & 90 & -16.68 & 10.46 & 3.08 & L3_25 & 2.5 & -1591 & 113 & -14.76 & 11.34 & 2.83 \\
\hline L1_25D & 2.5 & 1295 & 90 & -16.56 & 10.47 & 2.88 & L3_26 & 2.6 & -1595 & 114 & -15.16 & 10.87 & 3.00 \\
\hline
\end{tabular}


GLYNN ET AL. SUPPLEMENTAL FILE

\begin{tabular}{|c|c|c|c|c|c|c|c|c|c|c|c|c|c|}
\hline L1_26 & 2.6 & 1287 & 96 & -16.68 & 10.61 & 2.93 & L3_27 & 2.7 & -1599 & 111 & -15.32 & 11.07 & 2.98 \\
\hline L1_27 & 2.7 & 1278 & 94 & -16.70 & 10.50 & 3.02 & L3_28 & 2.8 & -1603 & 110 & -15.47 & 11.18 & 2.98 \\
\hline L1_28 & 2.8 & 1268 & 94 & -16.62 & 10.43 & 2.97 & L3_29 & 2.9 & -1607 & 109 & -15.49 & 11.03 & 2.94 \\
\hline L1_29 & 2.9 & 1259 & 95 & -16.62 & 10.24 & 2.97 & L3_30 & 3.0 & -1611 & 109 & -15.48 & 10.92 & 2.97 \\
\hline L1_30 & 3.0 & 1250 & 99 & -16.51 & 10.23 & 2.91 & L3_31 & 3.1 & -1615 & 109 & -15.52 & 10.50 & 3.03 \\
\hline L1_31 & 3.1 & 1241 & 103 & -16.56 & 9.98 & 2.94 & L3_32 & 3.2 & -1619 & 107 & -15.57 & 10.83 & 2.98 \\
\hline L1_32 & 3.2 & 1232 & 100 & -16.69 & 9.71 & 3.08 & L3_33 & 3.3 & -1623 & 106 & -15.44 & 10.51 & 3.00 \\
\hline L1_33 & 3.3 & 1222 & 98 & -16.70 & 9.97 & 2.96 & L3_34 & 3.4 & -1627 & 105 & -15.52 & 10.85 & 2.94 \\
\hline L1_34 & 3.4 & 1213 & 98 & -16.61 & 9.93 & 2.98 & L3_35 & 3.5 & -1631 & 104 & -15.65 & 10.80 & 2.96 \\
\hline L1_35 & 3.5 & 1203 & 100 & -16.60 & 10.04 & 2.94 & L3_36 & 3.6 & -1635 & 104 & -15.76 & 10.83 & 2.98 \\
\hline L1_36 & 3.6 & 1194 & 104 & -16.59 & 9.90 & 2.94 & L3_37 & 3.6 & -1640 & 103 & -15.92 & 10.92 & 2.94 \\
\hline L1_37 & 3.7 & 1184 & 102 & -16.53 & 9.95 & 2.95 & L3_38 & 3.8 & -1644 & 102 & -15.89 & 10.61 & 2.96 \\
\hline L1_38 & 3.8 & 1174 & 102 & -16.55 & 9.99 & 2.94 & L3_39 & 3.9 & -1648 & 101 & -15.86 & 10.64 & 2.93 \\
\hline L1_39 & 3.9 & 1165 & 104 & -16.58 & 9.95 & 2.90 & L3_40 & 4.0 & -1653 & 102 & -15.84 & 10.91 & 2.91 \\
\hline L1_40 & 4.0 & 1155 & 107 & -16.64 & 9.98 & 2.93 & L3_41 & 4.1 & -1657 & 102 & -15.91 & 11.01 & 2.95 \\
\hline L1_41 & 4.1 & 1145 & 113 & -16.62 & 10.03 & 2.92 & L3_42 & 4.2 & -1661 & 101 & -15.73 & 10.80 & 2.94 \\
\hline L1_42 & 4.2 & 1136 & 111 & -16.54 & 9.72 & 2.96 & L3_43 & 4.3 & -1666 & 100 & -15.79 & 10.67 & 2.96 \\
\hline L1_43 & 4.3 & 1126 & 110 & -16.73 & 10.31 & 2.95 & L3_44 & 4.4 & -1670 & 100 & -15.74 & 10.59 & 2.96 \\
\hline L1_44 & 4.4 & 1116 & 112 & -16.69 & 10.08 & 3.01 & L3_45 & 4.5 & -1674 & 100 & -15.69 & 10.65 & 2.97 \\
\hline L1_45 & 4.5 & 1106 & 115 & -16.70 & 10.29 & 2.92 & L3_46 & 4.6 & -1679 & 100 & -15.80 & 10.71 & 2.94 \\
\hline L1_45D & 4.5 & 1106 & 115 & -16.65 & 10.00 & 2.85 & L3_47 & 4.7 & -1683 & 99 & -15.84 & 10.71 & 2.96 \\
\hline L1_46 & 4.6 & 1097 & 120 & -16.68 & 10.26 & 2.88 & L3_48 & 4.8 & -1687 & 98 & -15.78 & 10.67 & 2.95 \\
\hline L1_47 & 4.7 & 1088 & 117 & -16.69 & 9.91 & 2.91 & L3_49 & 4.9 & -1692 & 97 & -15.89 & 10.91 & 2.96 \\
\hline L1_48 & 4.8 & 1078 & 115 & -16.79 & 10.27 & 2.97 & L3_50 & 5.0 & -1696 & 98 & -15.84 & 11.19 & 2.93 \\
\hline L1_49 & 4.9 & 1068 & 116 & -16.68 & 9.99 & 3.01 & L3_51 & 5.1 & -1701 & 98 & -15.98 & 11.57 & 2.97 \\
\hline L1_50 & 5.0 & 1058 & 118 & -16.53 & 9.93 & 2.92 & L3_52 & 5.2 & -1705 & 97 & -15.87 & 11.40 & 2.96 \\
\hline L1_51 & 5.1 & 1049 & 121 & -16.66 & 10.09 & 2.94 & L3_52D & 5.2 & -1705 & 97 & -16.02 & 11.44 & 2.94 \\
\hline L1_52 & 5.2 & 1039 & 118 & -16.67 & 10.23 & 2.91 & L3_53 & 5.3 & -1709 & 96 & -15.85 & 10.70 & 2.97 \\
\hline L1_53 & 5.3 & 1030 & 116 & -16.68 & 10.12 & 2.88 & L3_54 & 5.4 & -1714 & 95 & -15.92 & 10.68 & 2.92 \\
\hline L1_54 & 5.4 & 1020 & 116 & -16.59 & 9.96 & 2.94 & L3_55 & 5.4 & -1718 & 96 & -16.10 & 10.59 & 2.96 \\
\hline L1_55 & 5.5 & 1010 & 117 & -16.69 & 10.05 & 2.89 & L3_56 & 5.6 & -1722 & 97 & -16.01 & 10.71 & 2.97 \\
\hline L1_56 & 5.6 & 1000 & 120 & -16.63 & 9.90 & 2.88 & L3_57 & 5.7 & -1727 & 95 & -16.04 & 10.82 & 2.93 \\
\hline L1_57 & 5.7 & 991 & 115 & -16.63 & 10.06 & 2.93 & L3_58 & 5.8 & -1732 & 94 & -16.03 & 10.85 & 2.94 \\
\hline L1_58 & 5.8 & 981 & 112 & -16.55 & 10.04 & 2.91 & L3_59 & 5.9 & -1736 & 94 & -15.89 & 11.13 & 2.94 \\
\hline L1_59 & 5.9 & 972 & 111 & -16.66 & 9.94 & 2.93 & L3_60 & 6.0 & -1741 & 94 & -16.02 & 11.10 & 2.94 \\
\hline L1_60 & 6.0 & 962 & 111 & -16.62 & 9.87 & 2.91 & L3_61 & 6.1 & -1746 & 95 & -15.86 & 11.14 & 2.94 \\
\hline L1_61 & 6.1 & 953 & 112 & -16.63 & 9.77 & 2.96 & L3_62 & 6.2 & -1751 & 94 & -15.85 & 11.01 & 2.95 \\
\hline L1_62 & 6.2 & 943 & 107 & -16.67 & 9.77 & 2.99 & L3_63 & 6.3 & -1756 & 93 & -15.97 & 10.78 & 2.94 \\
\hline L1_63 & 6.3 & 933 & 103 & -16.72 & 9.80 & 2.98 & L3_64 & 6.4 & -1762 & 92 & -16.01 & 10.70 & 2.92 \\
\hline L1_64 & 6.4 & 924 & 101 & -16.58 & 9.76 & 2.96 & L3_65 & 6.5 & -1767 & 92 & -15.76 & 10.55 & 2.93 \\
\hline
\end{tabular}


GLYNN ET AL. SUPPLEMENTAL FILE

\begin{tabular}{|c|c|c|c|c|c|c|c|c|c|c|c|c|c|}
\hline L1_65 & 6.5 & 914 & 100 & -16.66 & 9.92 & 2.93 & L3_66 & 6.6 & -1773 & 94 & -15.77 & 10.54 & 2.92 \\
\hline L1_66 & 6.6 & 904 & 101 & -16.70 & 9.91 & 2.92 & L3_67 & 6.7 & -1778 & 92 & -15.79 & 10.76 & 2.97 \\
\hline L1_67 & 6.7 & 896 & 96 & -16.66 & 9.87 & 2.94 & L3_68 & 6.8 & -1783 & 91 & -15.69 & 10.97 & 2.91 \\
\hline L1_68 & 6.8 & 887 & 92 & -16.68 & 9.80 & 2.94 & L3_69 & 6.9 & -1788 & 90 & -15.75 & 10.75 & 2.97 \\
\hline L1_69 & 6.9 & 878 & 90 & -16.77 & 9.85 & 2.88 & L3_69D & 6.9 & -1788 & 90 & -15.87 & 10.86 & 2.95 \\
\hline L1_70 & 7.0 & 869 & 90 & -17.11 & 9.70 & 3.05 & L3_70 & 7.0 & -1794 & 91 & -15.86 & 10.74 & 2.93 \\
\hline L1_71 & 7.1 & 860 & 92 & -16.95 & 9.70 & 2.98 & L3_71 & 7.1 & -1799 & 92 & -15.94 & 10.56 & 2.93 \\
\hline L1_72 & 7.2 & 852 & 89 & -16.83 & 9.81 & 2.97 & L3_72 & 7.2 & -1804 & 91 & -15.92 & 10.72 & 2.94 \\
\hline L1_73 & 7.3 & 845 & 87 & -16.67 & 9.90 & 2.87 & L3_73 & 7.3 & -1810 & 90 & -16.02 & 10.70 & 2.95 \\
\hline L1_74 & 7.4 & 837 & 86 & -16.79 & 9.92 & 2.90 & L3_74 & 7.3 & -1815 & 90 & -15.89 & 10.78 & 2.91 \\
\hline L1_75 & 7.5 & 830 & 88 & -16.78 & 9.83 & 2.90 & L3_75 & 7.5 & -1820 & 90 & -15.99 & 10.83 & 2.89 \\
\hline L1_76 & 7.6 & 823 & 90 & -16.67 & 9.83 & 2.84 & L3_76 & 7.6 & -1825 & 91 & -15.89 & 10.80 & 2.91 \\
\hline L1_77 & 7.7 & 815 & 86 & -16.71 & 9.77 & 2.86 & L3_77 & 7.7 & -1831 & 89 & -15.85 & 10.95 & 2.91 \\
\hline L1_77D & 7.7 & 815 & 86 & -16.59 & 9.77 & 2.83 & L3_78 & 7.8 & -1836 & 88 & -15.94 & 10.82 & 2.89 \\
\hline L1_78 & 7.8 & 807 & 83 & -16.84 & 9.83 & 2.88 & L3_79 & 7.9 & -1841 & 87 & -15.95 & 11.21 & 2.94 \\
\hline L1_79 & 7.9 & 800 & 81 & -16.80 & 9.78 & 2.85 & L3_80 & 8.0 & -1846 & 88 & -15.80 & 11.21 & 2.90 \\
\hline L1_80 & 8.0 & 792 & 81 & -16.81 & 9.76 & 2.85 & L3_81 & 8.1 & -1851 & 89 & -16.01 & 11.12 & 2.93 \\
\hline L1_81 & 8.1 & 785 & 83 & -16.70 & 9.81 & 2.86 & L3_82 & 8.2 & -1857 & 88 & -15.92 & 11.09 & 2.91 \\
\hline L1_82 & 8.2 & 777 & 77 & -16.68 & 9.66 & 2.88 & L3_83 & 8.3 & -1862 & 88 & -15.87 & 11.07 & 2.87 \\
\hline L1_83 & 8.3 & 770 & 74 & -16.58 & 9.61 & 2.86 & L3_84 & 8.4 & -1867 & 88 & -15.75 & 10.97 & 2.88 \\
\hline L1_84 & 8.4 & 762 & 72 & -16.56 & 9.72 & 2.83 & L3_85 & 8.5 & -1872 & 89 & -15.77 & 11.00 & 2.91 \\
\hline L1_85 & 8.5 & 755 & 71 & -16.56 & 9.89 & 2.86 & L3_86 & 8.6 & -1878 & 91 & -15.80 & 10.57 & 2.89 \\
\hline L1_86 & 8.6 & 747 & 72 & -16.60 & 9.72 & 2.86 & L3_87 & 8.7 & -1883 & 91 & -15.87 & 10.82 & 2.88 \\
\hline L1_87 & 8.7 & 740 & 69 & -16.64 & 9.91 & 2.83 & L3_87D & 8.7 & -1883 & 91 & -15.97 & 10.62 & 2.88 \\
\hline L1_88 & 8.8 & 732 & 68 & -16.56 & 9.70 & 2.86 & L3_88 & 8.8 & -1888 & 91 & -15.94 & 10.93 & 2.89 \\
\hline L1_89 & 8.9 & 725 & 68 & -16.65 & 9.86 & 2.88 & L3_89 & 8.9 & -1893 & 91 & -15.90 & 10.89 & 2.88 \\
\hline L1_90 & 9.0 & 717 & 70 & -16.66 & 9.84 & 2.86 & L3_90 & 9.0 & -1898 & 93 & -15.70 & 11.18 & 2.86 \\
\hline L1_90D & 9.0 & 717 & 70 & -16.77 & 9.71 & 2.93 & L3_91 & 9.1 & -1903 & 95 & -15.90 & 11.40 & 2.90 \\
\hline L1_91 & 9.1 & 710 & 74 & -16.71 & 9.82 & 2.87 & L3_92 & 9.1 & -1908 & 94 & -16.10 & 11.16 & 2.93 \\
\hline L1_92 & 9.2 & 703 & 71 & -16.79 & 10.00 & 2.84 & L3_93 & 9.3 & -1913 & 94 & -16.00 & 11.34 & 2.94 \\
\hline L1_93 & 9.3 & 695 & 69 & -16.71 & 10.15 & 2.81 & L3_94 & 9.4 & -1918 & 95 & -15.97 & 11.28 & 2.89 \\
\hline L1_94 & 9.4 & 688 & 69 & -16.76 & 10.26 & 2.81 & L3_95 & 9.5 & -1923 & 96 & -15.80 & 11.18 & 2.89 \\
\hline L1_95 & 9.5 & 681 & 70 & -16.89 & 10.30 & 2.84 & L3_96 & 9.6 & -1928 & 98 & -15.81 & 11.50 & 3.04 \\
\hline L1_96 & 9.6 & 674 & 73 & -16.80 & 9.98 & 2.86 & L3_97 & 9.7 & -1933 & 97 & -15.86 & 11.50 & 2.90 \\
\hline L1_97 & 9.7 & 667 & 68 & -16.69 & 10.26 & 2.85 & L3_98 & 9.8 & -1938 & 96 & -15.62 & 11.10 & 3.01 \\
\hline L1_98 & 9.8 & 659 & 65 & -16.76 & 9.10 & 2.84 & L3_99 & 9.9 & -1944 & 97 & -16.16 & 10.94 & 3.00 \\
\hline L1_99 & 9.9 & 652 & 63 & -16.63 & 9.25 & 2.78 & L3_100 & 10.0 & -1949 & 98 & -16.00 & 10.55 & 3.01 \\
\hline L1_100 & 10.0 & 645 & 63 & -16.64 & 9.35 & 2.78 & L3_101 & 10.1 & -1954 & 100 & -16.09 & 10.81 & 3.04 \\
\hline L1_101 & 10.1 & 638 & 65 & -16.80 & 9.46 & 2.78 & L3_102 & 10.2 & -1959 & 99 & -16.45 & 10.82 & 2.97 \\
\hline L1_102 & 10.2 & 632 & 61 & -16.82 & 9.04 & 2.81 & L3_103 & 10.3 & -1964 & 99 & -16.14 & 10.90 & 2.92 \\
\hline
\end{tabular}


GLYNN ET AL. SUPPLEMENTAL FILE

\begin{tabular}{|c|c|c|c|c|c|c|c|c|c|c|c|c|c|}
\hline L1_103 & 10.3 & 625 & 59 & -16.73 & 9.21 & 2.79 & L3_104 & 10.4 & -1969 & 99 & -16.01 & 10.77 & 2.92 \\
\hline L1_104 & 10.4 & 619 & 59 & -16.83 & 9.39 & 2.81 & L3_105 & 10.5 & -1974 & 100 & -16.19 & 10.49 & 3.03 \\
\hline L1_105 & 10.5 & 613 & 60 & -16.83 & 8.97 & 2.83 & L3_106 & 10.6 & -1979 & 101 & -16.15 & 10.26 & 2.98 \\
\hline L1_106 & 10.6 & 606 & 63 & -16.76 & 9.08 & 2.87 & L3_107 & 10.7 & -1984 & 100 & -15.93 & 10.48 & 3.02 \\
\hline L1_107 & 10.7 & 601 & 62 & -16.72 & 9.12 & 2.83 & L3_107D & 10.7 & -1984 & 100 & -16.15 & 10.45 & 2.95 \\
\hline L1_108 & 10.8 & 596 & 62 & -16.71 & 9.24 & 2.78 & L3_108 & 10.8 & -1989 & 99 & -15.96 & 10.77 & 2.98 \\
\hline L1_108D & 10.8 & 596 & 62 & -16.89 & 8.92 & 2.81 & L3_109 & 10.9 & -1994 & 99 & -16.17 & 10.93 & 2.92 \\
\hline L1_109 & 10.9 & 590 & 63 & -16.82 & 9.23 & 2.83 & L3_110 & 11.0 & -1999 & 100 & -16.06 & 11.10 & 2.99 \\
\hline L1_110 & 11.0 & 585 & 65 & -16.77 & 9.34 & 2.78 & L3_111 & 11.1 & -2004 & 101 & -16.05 & 10.96 & 2.90 \\
\hline L1_111 & 11.1 & 579 & 68 & -16.70 & 9.52 & 2.77 & L3_112 & 11.2 & -2009 & 100 & -15.94 & 10.78 & 2.84 \\
\hline L1_112 & 11.2 & 574 & 67 & -16.77 & 9.51 & 2.80 & L3_113 & 11.3 & -2014 & 98 & -16.25 & 10.42 & 2.96 \\
\hline L1_113 & 11.3 & 569 & 66 & -16.84 & 9.12 & 2.97 & L3_114 & 11.4 & -2019 & 98 & -16.34 & 10.69 & 2.89 \\
\hline L1_114 & 11.4 & 564 & 66 & -16.96 & 9.52 & 2.78 & L3_115 & 11.5 & -2024 & 99 & -16.24 & 10.74 & 2.89 \\
\hline L1_115 & 11.5 & 558 & 68 & -16.89 & 9.75 & 2.81 & L3_116 & 11.6 & -2029 & 100 & -16.53 & 10.85 & 2.94 \\
\hline L1_116 & 11.6 & 553 & 70 & -17.04 & 9.24 & - & L3_117 & 11.7 & -2035 & 98 & -16.23 & 10.97 & 2.91 \\
\hline L1_117 & 11.7 & 548 & 68 & -16.91 & 9.64 & 2.74 & L3_118 & 11.8 & -2040 & 97 & -16.12 & 11.30 & 2.85 \\
\hline L1_118 & 11.8 & 542 & 67 & -16.78 & 9.68 & 2.79 & L3_119 & 11.9 & -2045 & 98 & -16.13 & 11.26 & 2.83 \\
\hline L1_119 & 11.9 & 537 & 67 & -16.85 & 9.45 & 2.88 & L3_120 & 12.0 & -2050 & 98 & -16.15 & 10.95 & 2.91 \\
\hline L1_120 & 12.0 & 531 & 69 & -16.92 & 9.63 & 2.81 & L3_121 & 12.1 & -2055 & 99 & -16.37 & 10.72 & 2.94 \\
\hline L1_121 & 12.1 & 526 & 71 & -16.76 & 9.57 & 2.85 & L3_122 & 12.2 & -2060 & 98 & -16.11 & 10.59 & 2.92 \\
\hline L1_122 & 12.2 & 521 & 70 & -16.67 & 9.64 & 2.82 & L3_123 & 12.3 & -2065 & 96 & -16.15 & 10.60 & 2.85 \\
\hline L1_123 & 12.3 & 516 & 70 & -16.71 & 9.56 & 2.81 & L3_124 & 12.4 & -2071 & 96 & -16.16 & 10.48 & 2.85 \\
\hline L1_124 & 12.4 & 511 & 71 & -16.79 & 9.77 & 2.80 & L3_125 & 12.5 & -2076 & 96 & -16.36 & 10.79 & 2.90 \\
\hline L1_125 & 12.5 & 506 & 73 & -16.85 & 9.92 & 2.78 & L3_126 & 12.6 & -2081 & 97 & -16.36 & 11.14 & 2.80 \\
\hline L1_126 & 12.6 & 501 & 75 & -16.79 & 9.56 & 2.80 & L3_127 & 12.6 & -2086 & 96 & -16.45 & 10.88 & 2.96 \\
\hline L1_127 & 12.7 & 496 & 74 & -16.78 & 9.33 & 2.79 & L3_128 & 12.8 & -2091 & 95 & -16.43 & 10.96 & 2.87 \\
\hline L1_128 & 12.8 & 491 & 74 & -16.82 & 9.25 & 2.85 & L3_129 & 12.9 & -2096 & 95 & -16.32 & 10.47 & 2.97 \\
\hline L1_129* & 12.9 & 486 & 75 & -17.79 & 9.13 & 3.21 & L3_129D & 12.9 & -2096 & 95 & -16.27 & 10.84 & 2.93 \\
\hline L1_130 & 13.0 & 481 & 76 & -16.91 & 9.07 & 2.80 & L3_130 & 13.0 & -2101 & 96 & -16.17 & 11.39 & 2.89 \\
\hline L1_130D & 13.0 & 481 & 76 & -16.90 & 9.22 & 2.86 & L3_131 & 13.1 & -2106 & 97 & -16.24 & 11.50 & 2.84 \\
\hline L1_131 & 13.1 & 476 & 78 & -16.95 & 9.03 & 2.84 & L3_132 & 13.2 & -2111 & 96 & -16.23 & 11.44 & 2.84 \\
\hline L1_132 & 13.2 & 471 & 77 & -17.01 & 8.99 & 2.82 & L3_133 & 13.3 & -2116 & 95 & -16.29 & 11.80 & 2.85 \\
\hline L1_133 & 13.3 & 466 & 76 & -16.98 & 9.12 & 2.84 & L3_134 & 13.4 & -2120 & 95 & -16.42 & 10.96 & 2.93 \\
\hline L1_134 & 13.4 & 461 & 77 & -17.10 & 9.18 & 2.86 & L3_135 & 13.5 & -2125 & 96 & -16.57 & 10.90 & 2.94 \\
\hline L1_135 & 13.5 & 457 & 78 & -17.10 & 9.56 & 2.84 & L3_136 & 13.6 & -2130 & 97 & -16.49 & 11.15 & 2.88 \\
\hline L1_136 & 13.6 & 452 & 80 & -17.11 & 9.40 & 2.86 & L3_137 & 13.7 & -2135 & 96 & -16.39 & 11.15 & 2.82 \\
\hline L1_137 & 13.7 & 447 & 79 & -17.15 & 9.33 & 2.85 & L3_138 & 13.8 & -2139 & 96 & -16.29 & 10.86 & 2.88 \\
\hline L1_138 & 13.8 & 442 & 80 & -17.03 & 9.41 & 2.80 & L3_139 & 13.9 & -2144 & 96 & -16.35 & 10.90 & 2.83 \\
\hline L1_139 & 13.9 & 437 & 81 & -17.11 & 9.43 & 2.73 & L3_140 & 14.0 & -2149 & 96 & -16.31 & 10.99 & 2.88 \\
\hline L1_140 & 14.0 & 432 & 83 & -17.16 & 9.37 & 2.87 & L3_141 & 14.1 & -2154 & 97 & -16.16 & 10.87 & 2.90 \\
\hline
\end{tabular}


GLYNN ET AL. SUPPLEMENTAL FILE

\begin{tabular}{|c|c|c|c|c|c|c|c|c|c|c|c|c|c|}
\hline L1_141 & 14.1 & 428 & 85 & -17.14 & 9.34 & 2.85 & L3_142 & 14.2 & -2159 & 96 & -16.27 & 11.33 & 2.84 \\
\hline L1_142 & 14.2 & 423 & 85 & -16.96 & 9.24 & 2.87 & L3_143 & 14.3 & -2163 & 95 & -16.34 & 11.39 & 2.84 \\
\hline L1_143 & 14.3 & 419 & 86 & -17.23 & 9.20 & 2.79 & L3_144 & 14.4 & -2168 & 96 & -16.39 & 11.18 & 2.91 \\
\hline L1_144 & 14.4 & 414 & 87 & -16.91 & 9.33 & 2.88 & L3_145 & 14.5 & -2173 & 96 & -16.47 & 10.88 & 2.93 \\
\hline L1_145 & 14.5 & 410 & 89 & -17.11 & 9.08 & 2.81 & L3_146* & 14.6 & -2178 & 97 & -17.10 & 11.18 & 3.10 \\
\hline L1_146 & 14.6 & 405 & 92 & -16.74 & 8.85 & 2.94 & L3_147 & 14.7 & -2183 & 96 & -16.29 & 10.99 & 2.86 \\
\hline L1_147 & 14.7 & 401 & 91 & -17.10 & 9.26 & 2.86 & L3_148 & 14.8 & -2188 & 96 & -16.25 & 11.04 & 2.84 \\
\hline L1_148 & 14.8 & 396 & 92 & -16.98 & 9.46 & 2.84 & L3_148D & 14.8 & -2188 & 96 & -16.21 & 10.72 & 2.94 \\
\hline L1_149 & 14.9 & 392 & 93 & -17.08 & 9.61 & 2.81 & L3_149 & 14.9 & -2192 & 96 & -16.15 & 11.31 & 2.83 \\
\hline L1_150 & 15.0 & 387 & 95 & -17.02 & 9.39 & 2.71 & L3_150 & 15.0 & -2197 & 97 & -16.38 & 11.55 & 2.79 \\
\hline L1_150D & 15.0 & 387 & 95 & -17.00 & 9.61 & 2.88 & L3_151 & 15.1 & -2202 & 98 & -16.18 & 11.19 & 2.87 \\
\hline L1_151 & 15.1 & 383 & 97 & -17.04 & 9.32 & 2.88 & L3_152 & 15.2 & -2207 & 97 & -16.28 & 11.16 & 2.85 \\
\hline L1_152 & 15.2 & 378 & 96 & -17.05 & 9.52 & 2.88 & L3_153 & 15.3 & -2213 & 97 & -16.20 & 11.21 & 2.85 \\
\hline L1_153 & 15.3 & 373 & 96 & -16.89 & 9.63 & 2.89 & L3_154 & 15.4 & -2218 & 97 & -16.48 & 11.07 & 2.84 \\
\hline L1_154 & 15.4 & 368 & 98 & -17.00 & 9.65 & 2.85 & L3_155 & 15.5 & -2224 & 98 & -16.31 & 11.19 & 2.78 \\
\hline L1_155 & 15.5 & 364 & 99 & -17.19 & 9.51 & 2.89 & L3_156 & 15.6 & -2229 & 100 & -16.35 & 11.31 & 2.84 \\
\hline L1_156 & 15.6 & 359 & 102 & -17.06 & 9.82 & 2.77 & L3_157 & 15.7 & -2235 & 98 & -16.24 & 11.29 & 2.88 \\
\hline L1_157 & 15.7 & 352 & 102 & -17.12 & 9.86 & 2.81 & L3_158 & 15.8 & -2241 & 99 & -16.22 & 11.27 & 2.88 \\
\hline L1_158 & 15.8 & 346 & 103 & -17.12 & 9.70 & 2.75 & L3_159 & 15.9 & -2247 & 99 & -16.20 & 11.30 & 2.87 \\
\hline L1_159 & 15.9 & 339 & 105 & -17.05 & 9.67 & 2.80 & L3_160 & 16.0 & -2253 & 101 & -16.40 & 11.48 & 2.90 \\
\hline L1_160 & 16.0 & 333 & 108 & -17.11 & 9.88 & 2.87 & L3_161 & 16.1 & -2259 & 103 & -16.30 & 11.29 & 2.82 \\
\hline L1_161 & 16.1 & 326 & 112 & -17.11 & 9.34 & 2.86 & L3_162 & 16.2 & -2265 & 102 & -16.26 & 11.25 & 2.79 \\
\hline L1_162 & 16.2 & 319 & 111 & -17.00 & 9.54 & 2.79 & L3_163 & 16.3 & -2271 & 101 & -16.29 & 11.28 & 2.79 \\
\hline L1_163 & 16.3 & 313 & 112 & -17.06 & 9.30 & 2.86 & L3_164 & 16.4 & -2277 & 101 & -16.34 & 10.98 & 2.87 \\
\hline L1_164 & 16.4 & 306 & 113 & -16.93 & 9.75 & 2.75 & L3_165 & 16.5 & -2282 & 102 & -16.30 & 10.93 & 2.91 \\
\hline L1_165 & 16.5 & 299 & 116 & -17.06 & 9.02 & 2.93 & L3_166 & 16.6 & -2288 & 104 & -16.34 & 10.70 & 2.84 \\
\hline L1_166 & 16.6 & 292 & 119 & -17.11 & 9.06 & 2.91 & L3_167 & 16.7 & -2294 & 103 & -16.55 & 10.61 & 2.88 \\
\hline L1_166D & 16.6 & 292 & 119 & -16.93 & 9.15 & 2.91 & L3_167D & 16.7 & -2294 & 103 & -16.41 & 10.65 & 2.91 \\
\hline L1_167 & 16.7 & 286 & 118 & -17.04 & 9.26 & 2.83 & L3_168* & 16.8 & -2300 & 102 & -14.79 & 11.70 & 2.80 \\
\hline L1_168 & 16.8 & 279 & 118 & -17.04 & 9.10 & 2.82 & L3_169 & 16.9 & -2306 & 102 & -16.53 & 10.82 & 2.88 \\
\hline L1_169 & 16.9 & 272 & 118 & -17.05 & 9.09 & 2.82 & L3_170 & 17.0 & -2312 & 103 & -16.62 & 10.54 & 2.83 \\
\hline L1_170 & 17.0 & 266 & 120 & -17.03 & 9.34 & 2.81 & L3_171 & 17.1 & -2318 & 105 & -16.50 & 10.64 & 2.88 \\
\hline L1_171 & 17.1 & 259 & 123 & -17.11 & 9.27 & 2.74 & L3_172 & 17.2 & -2324 & 103 & -16.54 & 10.59 & 2.84 \\
\hline L1_172 & 17.2 & 250 & 123 & -17.03 & 9.19 & 2.78 & L3_173 & 17.3 & -2330 & 102 & -16.59 & 10.66 & 2.89 \\
\hline L1_173 & 17.3 & 241 & 126 & -17.01 & 8.76 & 2.88 & L3_174 & 17.4 & -2336 & 102 & -16.61 & 10.79 & 2.84 \\
\hline L1_174 & 17.4 & 232 & 131 & -16.93 & 8.90 & 2.81 & L3_175 & 17.5 & -2342 & 103 & -16.58 & 10.57 & 2.89 \\
\hline \multirow[t]{2}{*}{ L1_175 } & 17.5 & 222 & 137 & -17.20 & 9.18 & 2.82 & L3_176 & 17.6 & -2348 & 104 & -16.76 & 10.52 & 2.83 \\
\hline & & & & & & & L3_177 & 17.7 & -2355 & 102 & -16.65 & 10.61 & 2.85 \\
\hline L2_1* & 0.1 & 27 & 135 & -16.32 & 9.85 & 3.53 & L3_178 & 17.8 & -2363 & 102 & -16.76 & 10.50 & 2.92 \\
\hline L2_2* & 0.2 & 22 & 133 & -17.01 & 9.18 & 3.80 & L3_179 & 17.9 & -2371 & 103 & -16.62 & 10.60 & 2.84 \\
\hline
\end{tabular}


GLYNN ET AL. SUPPLEMENTAL FILE

\begin{tabular}{|c|c|c|c|c|c|c|c|c|c|c|c|c|c|}
\hline L2_3* & 0.3 & 18 & 132 & -15.72 & 9.01 & 3.32 & L3_180 & 18.0 & -2378 & 105 & -16.65 & 10.75 & 2.89 \\
\hline L2_4* & 0.4 & 13 & 131 & -15.53 & 9.32 & 3.17 & L3_181 & 18.1 & -2386 & 108 & -16.60 & 10.72 & 2.84 \\
\hline L2_5* & 0.5 & 8 & 131 & -15.65 & 9.54 & 3.02 & L3_182 & 18.2 & -2394 & 106 & -16.71 & 10.49 & 2.90 \\
\hline L2_6* & 0.6 & 3 & 130 & -15.79 & 8.94 & 3.23 & L3_183 & 18.3 & -2402 & 105 & -16.58 & 10.88 & 2.87 \\
\hline L2_7* & 0.7 & -2 & 128 & -15.94 & 8.97 & 3.16 & L3_184 & 18.4 & -2410 & 105 & -16.62 & 11.11 & 2.84 \\
\hline L2_8* & 0.8 & -7 & 126 & -15.60 & 8.84 & 3.06 & L3_185 & 18.5 & -2418 & 107 & -16.64 & 10.89 & 2.92 \\
\hline L2_9* & 0.9 & -12 & 125 & -15.94 & 8.86 & 3.10 & L3_186 & 18.6 & -2426 & 109 & -16.63 & 11.09 & 2.94 \\
\hline L2_10 & 1.0 & -17 & 123 & -16.04 & 9.16 & 3.04 & L3_186D & 18.6 & -2426 & 109 & -16.52 & 11.12 & 2.89 \\
\hline L2_11* & 1.1 & -22 & 123 & -16.05 & 8.68 & 3.13 & L3_187 & 18.7 & -2434 & 106 & -16.61 & 10.96 & 2.93 \\
\hline L2_12* & 1.2 & -27 & 121 & -16.18 & 9.10 & 3.19 & L3_188 & 18.8 & -2442 & 104 & -16.59 & 10.86 & 2.90 \\
\hline L2_13 & 1.3 & -32 & 119 & -16.35 & 9.43 & 3.05 & L3_189 & 18.9 & -2450 & 103 & -16.53 & 10.99 & 2.90 \\
\hline L2_14 & 1.4 & -37 & 118 & -16.25 & 9.33 & 3.07 & L3_190 & 19.0 & -2458 & 104 & -16.58 & 11.03 & 2.90 \\
\hline L2_15 & 1.5 & -42 & 118 & -16.29 & 9.66 & 3.00 & L3_191 & 19.1 & -2466 & 107 & -16.52 & 11.25 & 2.89 \\
\hline L2_16 & 1.6 & -47 & 118 & -16.29 & 9.67 & 3.01 & L3_192 & 19.2 & -2474 & 103 & -16.58 & 11.15 & 2.90 \\
\hline L2_17 & 1.7 & -51 & 117 & -16.22 & 9.59 & 2.93 & L3_193 & 19.3 & -2481 & 99 & -16.60 & 10.68 & 2.92 \\
\hline L2_18 & 1.8 & -55 & 116 & -16.36 & 9.41 & 3.00 & L3_194 & 19.4 & -2489 & 99 & -16.47 & 10.56 & 2.91 \\
\hline L2_18D & 1.8 & -55 & 116 & -16.22 & 9.56 & 2.90 & L3_195 & 19.5 & -2497 & 99 & -16.47 & 10.28 & 2.93 \\
\hline L2_19 & 1.9 & -59 & 115 & -16.34 & 9.31 & 3.01 & L3_196 & 19.6 & -2505 & 100 & -16.58 & 10.57 & 2.92 \\
\hline L2_20 & 2.0 & -63 & 115 & -16.23 & 9.47 & 2.92 & L3_197 & 19.7 & -2512 & 97 & -16.59 & 10.56 & 2.89 \\
\hline L2_21 & 2.1 & -67 & 115 & -16.21 & 9.07 & 3.08 & L3_198 & 19.8 & -2519 & 96 & -16.51 & 10.61 & 2.89 \\
\hline L2_22 & 2.2 & -71 & 114 & -16.08 & 9.51 & 2.94 & L3_199 & 19.9 & -2526 & 95 & -16.55 & 10.50 & 2.90 \\
\hline L2_23 & 2.3 & -75 & 113 & -16.26 & 9.55 & 3.02 & L3_200 & 20.0 & -2533 & 96 & -16.54 & 10.75 & 2.89 \\
\hline L2_24 & 2.4 & -78 & 112 & -16.15 & 9.80 & 2.92 & L3_201 & 20.1 & -2540 & 98 & - & - & - \\
\hline L2_25 & 2.5 & -82 & 112 & -15.88 & 9.60 & 2.96 & L3_202 & 20.2 & -2545 & 97 & - & - & - \\
\hline L2_26 & 2.6 & -86 & 112 & -15.63 & 9.56 & 3.02 & L3_203 & 20.3 & -2551 & 96 & -16.53 & 11.53 & 2.88 \\
\hline L2_27 & 2.7 & -89 & 110 & -15.83 & 9.38 & 3.02 & L3_204 & 20.4 & -2556 & 97 & - & - & - \\
\hline L2_28* & 2.8 & -93 & 109 & -15.46 & 9.48 & 3.03 & L3_205 & 20.5 & -2561 & 98 & - & - & - \\
\hline L2_29 & 2.9 & -97 & 109 & - & - & - & L3_206 & 20.6 & -2567 & 99 & - & - & - \\
\hline L2_30 & 3.0 & -100 & 109 & -16.26 & 8.94 & 2.99 & L3_207 & 20.7 & -2572 & 98 & - & - & - \\
\hline L2_31 & 3.1 & -104 & 108 & -16.31 & 8.71 & 2.98 & L3_208 & 20.8 & -2577 & 97 & - & - & - \\
\hline L2_32 & 3.2 & -108 & 107 & -16.44 & 9.01 & 2.93 & L3_209 & 20.9 & -2582 & 97 & - & - & - \\
\hline L2_33 & 3.3 & -112 & 106 & -16.32 & 8.69 & 2.92 & L3_210 & 21.0 & -2587 & 97 & - & - & - \\
\hline L2_34 & 3.4 & -115 & 106 & -16.32 & 8.55 & 3.00 & L3_211 & 21.1 & -2592 & 98 & - & - & - \\
\hline L2_35 & 3.5 & -119 & 106 & -16.09 & 8.72 & 2.85 & L3_212 & 21.2 & -2598 & 97 & -16.65 & 10.48 & 2.92 \\
\hline L2_36 & 3.6 & -123 & 105 & -16.05 & 9.00 & 2.91 & L3_213 & 21.3 & -2603 & 96 & - & 10.92 & - \\
\hline L2_36D & 3.6 & -123 & 105 & -16.06 & 9.22 & 2.84 & L3_214 & 21.4 & -2608 & 96 & -16.67 & 11.07 & 2.90 \\
\hline L2_37 & 3.7 & -128 & 104 & -16.24 & 9.60 & 2.90 & L3_215 & 21.5 & -2613 & 97 & -16.53 & 11.02 & 2.89 \\
\hline L2_38 & 3.8 & -132 & 103 & - & - & - & L3_216 & 21.6 & -2619 & 98 & -16.55 & 11.16 & 2.89 \\
\hline L2_39 & 3.9 & -137 & 102 & - & - & - & L3_217 & 21.7 & -2624 & 96 & -16.65 & 10.94 & 2.96 \\
\hline L2_40 & 4.0 & -142 & 103 & -16.44 & 9.67 & 2.88 & L3_218 & 21.8 & -2629 & 96 & -16.71 & 11.26 & 2.96 \\
\hline
\end{tabular}




\begin{tabular}{|c|c|c|c|c|c|c|c|c|c|c|c|c|c|}
\hline L2_41 & 4.1 & -146 & 103 & - & - & - & L3_219 & 21.9 & -2634 & 96 & -16.69 & 11.05 & 2.96 \\
\hline L2_42 & 4.2 & -151 & 102 & - & - & - & L3_220 & 22.0 & -2639 & 96 & -16.67 & 10.98 & 2.90 \\
\hline L2_43 & 4.3 & -156 & 101 & -16.38 & 8.68 & 2.85 & L3_221 & 22.1 & -2644 & 98 & -16.66 & 11.07 & 2.94 \\
\hline L2_44 & 4.4 & -160 & 101 & -16.23 & 8.73 & 2.86 & L3_222 & 22.2 & -2650 & 96 & -16.62 & 11.02 & 2.92 \\
\hline L2_45 & 4.5 & -165 & 101 & -16.28 & 8.46 & 3.01 & L3_223 & 22.3 & -2655 & 95 & -16.55 & 10.83 & 2.94 \\
\hline L2_46 & 4.6 & -170 & 102 & -16.24 & 8.77 & 2.84 & L3_224 & 22.4 & -2661 & 95 & -16.58 & 10.74 & 2.95 \\
\hline L2_47 & 4.7 & -174 & 100 & -16.23 & 8.83 & 2.82 & L3_225 & 22.5 & -2667 & 95 & -16.44 & 10.93 & 2.96 \\
\hline L2_48 & 4.8 & -179 & 99 & -15.97 & 8.39 & 2.89 & L3_226 & 22.6 & -2672 & 97 & -16.46 & 10.59 & 2.99 \\
\hline L2_49 & 4.9 & -184 & 98 & -16.17 & 8.50 & 2.85 & L3_227 & 22.7 & -2678 & 96 & -16.57 & 10.65 & 2.92 \\
\hline L2_50 & 5.0 & -188 & 99 & -16.18 & 8.74 & 2.93 & L3_227D & 22.7 & -2678 & 96 & -16.62 & 10.72 & 2.91 \\
\hline L2_51 & 5.1 & -193 & 99 & -16.28 & 9.03 & 2.88 & L3_228 & 22.8 & -2683 & 96 & -16.74 & 10.73 & 2.90 \\
\hline L2_52 & 5.2 & -198 & 98 & -16.19 & 9.12 & 2.87 & L3_229 & 22.9 & -2689 & 96 & -16.81 & 10.58 & 2.92 \\
\hline L2_53 & 5.3 & -202 & 97 & -16.34 & 9.27 & 2.86 & L3_230 & 23.0 & -2695 & 97 & -16.70 & 10.68 & 2.95 \\
\hline L2_54 & 5.4 & -207 & 96 & -16.38 & 9.42 & 2.88 & L3_231 & 23.1 & -2700 & 99 & -16.92 & 10.66 & 2.92 \\
\hline L2_54D & 5.4 & -207 & 96 & -16.28 & 9.48 & 2.81 & L3_232 & 23.2 & -2706 & 98 & -16.84 & 10.27 & 2.93 \\
\hline L2_55 & 5.5 & -212 & 97 & -16.33 & 9.49 & 2.82 & L3_233 & 23.3 & -2712 & 97 & -16.78 & 10.19 & 2.94 \\
\hline L2_56 & 5.6 & -217 & 97 & -16.45 & 9.26 & 2.94 & L3_234 & 23.4 & -2717 & 97 & -16.76 & 10.04 & 2.92 \\
\hline L2_57 & 5.7 & -222 & 96 & -16.44 & 9.41 & 2.92 & L3_235 & 23.5 & -2723 & 98 & -16.72 & 10.20 & 2.90 \\
\hline L2_58 & 5.8 & -226 & 95 & -16.44 & 9.23 & 2.97 & L3_236 & 23.6 & -2729 & 99 & -16.62 & 10.34 & 2.92 \\
\hline L2_59 & 5.9 & -231 & 95 & -16.42 & 9.39 & 2.87 & L3_237 & 23.7 & -2735 & 97 & -16.88 & 10.76 & 2.95 \\
\hline L2_60 & 6.0 & -236 & 96 & -16.48 & 9.40 & 2.88 & L3_238 & 23.8 & -2740 & 95 & -16.67 & 10.73 & 2.91 \\
\hline L2_61 & 6.1 & -240 & 97 & -16.65 & 9.26 & 2.93 & L3_239 & 23.9 & -2746 & 95 & -16.66 & 10.81 & 2.91 \\
\hline L2_62 & 6.2 & -245 & 95 & -16.42 & 9.41 & 2.89 & L3_240 & 24.0 & -2752 & 95 & -16.67 & 10.85 & 2.91 \\
\hline L2_63 & 6.3 & -250 & 95 & -16.56 & 9.11 & 2.87 & L3_241 & 24.1 & -2758 & 96 & -16.73 & 10.77 & 2.91 \\
\hline L2_64 & 6.4 & -255 & 94 & -16.44 & 9.47 & 2.83 & L3_241D & 24.1 & -2758 & 96 & -16.65 & 10.64 & 3.04 \\
\hline L2_65 & 6.5 & -260 & 94 & -16.24 & 9.68 & 2.87 & L3_242 & 24.2 & -2763 & 95 & -16.68 & 10.65 & 2.92 \\
\hline L2_66 & 6.6 & -264 & 95 & -16.44 & 9.71 & 2.85 & L3_243 & 24.3 & -2769 & 93 & -16.82 & 10.65 & 2.93 \\
\hline L2_67 & 6.7 & -269 & 93 & -16.54 & 9.14 & 3.00 & L3_244 & 24.4 & -2774 & 93 & -16.88 & 10.47 & 2.94 \\
\hline L2_68 & 6.8 & -274 & 93 & -16.41 & 9.17 & 2.84 & L3_245 & 24.5 & -2780 & 93 & -16.87 & 10.56 & 2.93 \\
\hline L2_69 & 6.9 & -279 & 92 & -16.40 & 9.05 & 2.88 & L3_246 & 24.6 & -2785 & 94 & -16.83 & 10.68 & 2.91 \\
\hline L2_70 & 7.0 & -284 & 92 & -16.43 & 9.14 & 2.89 & L3_247 & 24.7 & -2792 & 93 & -16.90 & 10.46 & 2.92 \\
\hline L2_71 & 7.1 & -289 & 93 & -16.32 & 8.95 & 2.86 & L3_248 & 24.8 & -2797 & 93 & -16.95 & 10.50 & 2.91 \\
\hline L2_72 & 7.2 & -293 & 92 & -16.13 & 8.68 & 2.86 & L3_249 & 24.9 & -2803 & 94 & -16.90 & 10.60 & 2.88 \\
\hline L2_73 & 7.3 & -297 & 92 & -16.34 & 8.91 & 2.90 & L3_250 & 25.0 & -2809 & 96 & -16.91 & 10.54 & 2.93 \\
\hline L2_73D & 7.3 & -297 & 92 & -16.22 & 8.87 & 2.91 & L3_251 & 25.1 & -2815 & 98 & -16.82 & 10.69 & 2.90 \\
\hline L2_74 & 7.4 & -301 & 93 & -16.68 & 9.62 & 2.93 & L3_252 & 25.2 & -2821 & 98 & -16.77 & 10.50 & 2.92 \\
\hline L2_75 & 7.5 & -305 & 94 & -16.58 & 9.57 & 2.86 & L3_253 & 25.3 & -2827 & 99 & -16.77 & 10.43 & 2.90 \\
\hline L2_76 & 7.6 & -309 & 96 & -16.53 & 9.49 & 2.88 & L3_254 & 25.4 & -2833 & 100 & -16.74 & 10.32 & 2.90 \\
\hline L2_77 & 7.7 & -313 & 95 & -16.72 & 9.58 & 2.86 & L3_255 & 25.5 & -2839 & 102 & -17.12 & 10.24 & 2.90 \\
\hline L2_78 & 7.8 & -317 & 95 & -16.67 & 9.57 & 2.77 & L3_256 & 25.6 & -2845 & 105 & -17.09 & 10.26 & 2.91 \\
\hline
\end{tabular}


GLYNN ET AL. SUPPLEMENTAL FILE

\begin{tabular}{|c|c|c|c|c|c|c|c|c|c|c|c|c|c|}
\hline L2_79 & 7.9 & -321 & 95 & -16.59 & 9.59 & 2.81 & L3_257 & 25.7 & -2851 & 105 & -17.16 & 10.43 & 2.90 \\
\hline L2_80 & 8.0 & -325 & 96 & -16.42 & 9.47 & 2.88 & L3_258 & 25.8 & -2857 & 105 & -17.10 & 10.38 & 2.94 \\
\hline L2_81 & 8.1 & -329 & 97 & -16.39 & 9.50 & 2.88 & L3_258D & 25.8 & -2857 & 105 & -17.26 & 10.36 & 2.89 \\
\hline L2_82 & 8.2 & -333 & 96 & -16.45 & 9.57 & 2.84 & L3_259 & 25.9 & -2863 & 105 & -17.02 & 10.38 & 2.93 \\
\hline L2_83 & 8.3 & -337 & 96 & -16.66 & 9.45 & 2.84 & L3_260 & 26.0 & -2869 & 107 & -16.87 & 10.58 & 2.93 \\
\hline L2_84 & 8.4 & -341 & 97 & -16.54 & 9.20 & 2.85 & L3_261 & 26.1 & -2875 & 109 & -16.84 & 10.57 & 2.92 \\
\hline L2_85 & 8.5 & -345 & 97 & -16.35 & 9.05 & 2.83 & L3_262 & 26.2 & -2881 & 109 & - & - & - \\
\hline L2_86 & 8.6 & -349 & 97 & -16.41 & 8.97 & 2.86 & L3_263 & 26.3 & -2887 & 109 & -16.77 & 10.58 & 2.93 \\
\hline L2_87 & 8.7 & -353 & 97 & -16.50 & 9.31 & 2.79 & L3_264 & 26.4 & -2893 & 109 & - & - & - \\
\hline L2_88 & 8.8 & -358 & 96 & -16.63 & 9.44 & 2.83 & L3_265 & 26.5 & -2899 & 111 & - & - & - \\
\hline L2_89 & 8.9 & -362 & 96 & -16.64 & 9.47 & 2.91 & L3_266 & 26.6 & -2905 & 113 & - & - & - \\
\hline L2_90 & 9.0 & -366 & 96 & -16.74 & 9.65 & 2.83 & L3_267 & 26.7 & -2910 & 114 & -16.65 & 10.28 & 2.91 \\
\hline L2_91 & 9.1 & -370 & 97 & -16.96 & 9.69 & 2.92 & L3_268 & 26.8 & -2916 & 114 & -16.74 & 10.07 & 2.91 \\
\hline L2_91D & 9.1 & -370 & 97 & -16.77 & 8.95 & 2.83 & L3_269 & 26.9 & -2921 & 116 & -16.84 & 10.36 & 2.93 \\
\hline L2_92 & 9.2 & -376 & 96 & -16.71 & 9.35 & 2.83 & L3_270 & 27.0 & -2927 & 118 & -16.65 & 10.18 & 2.93 \\
\hline L2_93 & 9.3 & -382 & 95 & -16.77 & 8.96 & 2.91 & L3_271 & 27.1 & -2932 & 120 & -16.59 & 10.46 & 2.92 \\
\hline L2_94 & 9.4 & -388 & 95 & -16.70 & 9.17 & 2.86 & L3_272 & 27.2 & -2937 & 121 & -16.70 & 10.43 & 2.92 \\
\hline L2_95 & 9.5 & -393 & 95 & -16.55 & 9.25 & 2.84 & L3_272D & 27.2 & -2937 & 121 & -16.53 & 10.31 & 2.93 \\
\hline L2_96 & 9.6 & -399 & 96 & -16.67 & 9.34 & 2.82 & L3_273 & 27.3 & -2942 & 122 & -16.89 & 10.29 & 3.03 \\
\hline L2_97 & 9.7 & -405 & 95 & -16.60 & 9.22 & 2.87 & L3_274 & 27.4 & -2947 & 123 & -16.55 & 10.90 & 2.92 \\
\hline L2_98 & 9.8 & -411 & 94 & -16.47 & 9.42 & 2.84 & L3_275 & 27.5 & -2952 & 125 & -16.64 & 10.93 & 2.90 \\
\hline L2_99 & 9.9 & -417 & 94 & -16.41 & 9.46 & 2.83 & L3_276 & 27.6 & -2958 & 127 & -16.67 & 11.24 & 2.90 \\
\hline L2_100 & 10.0 & -423 & 95 & -16.47 & 9.63 & 2.82 & & & & & & & \\
\hline L2_101 & 10.1 & -429 & 97 & -16.80 & 9.97 & 2.81 & & & & & & & \\
\hline L2_102 & 10.2 & -434 & 95 & -16.71 & 10.03 & 2.80 & & & & & & & \\
\hline L2_103 & 10.3 & -440 & 94 & -16.71 & 9.76 & 2.81 & & & & & & & \\
\hline L2_104 & 10.4 & -446 & 94 & -16.62 & 9.70 & 2.81 & & & & & & & \\
\hline L2_105 & 10.5 & -452 & 95 & -16.62 & 9.70 & 2.79 & & & & & & & \\
\hline L2_106 & 10.6 & -458 & 96 & -16.68 & 9.28 & 2.85 & & & & & & & \\
\hline L2_107 & 10.7 & -463 & 94 & -16.63 & 9.45 & 2.77 & & & & & & & \\
\hline L2_108 & 10.8 & -469 & 94 & -16.48 & 9.16 & 2.76 & & & & & & & \\
\hline L2_109 & 10.9 & -474 & 95 & -16.58 & 9.10 & 2.77 & & & & & & & \\
\hline L2_110 & 11.0 & -479 & 96 & -16.43 & 9.18 & 2.75 & & & & & & & \\
\hline L2_111 & 11.1 & -485 & 98 & -16.76 & 9.21 & 2.82 & & & & & & & \\
\hline L2_112 & 11.2 & -490 & 98 & -16.63 & 8.99 & 2.83 & & & & & & & \\
\hline L2_113 & 11.3 & -495 & 98 & -16.54 & 9.29 & 2.73 & & & & & & & \\
\hline L2_114 & 11.4 & -501 & 99 & -16.52 & 9.34 & 2.73 & & & & & & & \\
\hline L2_115 & 11.5 & -506 & 101 & - & - & - & & & & & & & \\
\hline L2_116 & 11.6 & -511 & 104 & - & - & - & & & & & & & \\
\hline L2_117 & 11.7 & -516 & 103 & -16.65 & 9.32 & 2.81 & & & & & & & \\
\hline
\end{tabular}




\begin{tabular}{|ccccccc|}
\hline L2_118 & 11.8 & -521 & 103 & -16.52 & 9.14 & 2.75 \\
\hline L2_119 & 11.9 & -527 & 105 & -16.50 & 9.30 & 2.72 \\
\hline L2_120 & 12.0 & -532 & 106 & -16.57 & 9.27 & 2.70 \\
\hline L2_121 & 12.1 & -537 & 109 & -16.37 & 9.18 & 2.70 \\
\hline L2_122 & 12.2 & -542 & 108 & -16.68 & 9.12 & 2.77 \\
\hline L2_123 & 12.3 & -547 & 109 & -16.47 & 8.92 & 2.78 \\
\hline L2_124 & 12.4 & -552 & 110 & -16.48 & 9.17 & 2.74 \\
\hline L2_125 & 12.5 & -557 & 112 & -16.68 & 9.13 & 2.80 \\
\hline L2_126 & 12.6 & -562 & 114 & -16.39 & 9.05 & 2.96 \\
\hline L2_126D & 12.6 & -562 & 114 & -16.78 & 8.68 & 2.79 \\
\hline L2_127 & 12.7 & -567 & 114 & -16.57 & 9.10 & 2.74 \\
\hline L2_128 & 12.8 & -572 & 116 & -16.66 & 8.99 & 2.83 \\
\hline L2_129 & 12.9 & -578 & 117 & -16.74 & 8.78 & 2.79 \\
\hline L2_130 & 13.0 & -583 & 119 & -16.83 & 9.03 & 2.84 \\
\hline
\end{tabular}


Supplemental Data Table $3 \mid$ Sensitivity of $\delta^{13} \mathrm{C}$ according to different environmental variables.

\begin{tabular}{|c|c|c|c|c|}
\hline Variable & $\delta^{13} \mathrm{C}$ sensitivity & $\begin{array}{c}\text { Surface Seasonal } \\
\text { Variable Range }\end{array}$ & $\begin{array}{c}\text { Theoretical } \\
\text { Seasonal } \Delta \delta^{13} \mathbf{C}\end{array}$ & References \\
\hline Temperature on $\varepsilon_{\mathrm{p}}$ & $0.12 \%$ / ${ }^{\circ} \mathrm{C}$ & $24-27^{\circ} \mathrm{C}$ & $0.36 \%$ & $\begin{array}{l}\text { Locarnini et al. 2010, } \\
\text { Young et al. } 2013\end{array}$ \\
\hline $\begin{array}{c}\text { Temperature on } \\
\delta^{13} C_{\text {plankton }}\end{array}$ & $0.11 \% 0 /{ }^{\circ} \mathrm{C}^{*}$ & $24-27^{\circ} \mathrm{C}$ & $0.33 \%$ & Rau et al. 1996 \\
\hline $\begin{array}{c}\text { Temperature on } \\
\delta^{13} \mathrm{C}_{\text {plankton }}\end{array}$ & $0.23 \%$ / ${ }^{\circ} \mathrm{C}$ & $24-27^{\circ} \mathrm{C}$ & $0.69 \%$ & Rau et al. 1989 \\
\hline $\begin{array}{l}\text { Temperature on } \\
\text { suspended POC }\end{array}$ & $0.41 \%{ }^{\circ}{ }^{\circ} \mathrm{C}$ & $24-27^{\circ} \mathrm{C}$ & $1.23 \%$ & Rau et al. 1992 \\
\hline $\mathrm{pH}$ & $2.7 \%_{0} / 0.1 \mathrm{pH}$ & $8.085-8.115 \mathrm{pH}$ & $0.08 \%$ & $\begin{array}{l}\text { Hinga et al. 1994, } \\
\text { Dore et al. } 2009\end{array}$ \\
\hline Salinity on $\varepsilon_{\mathrm{p}}$ & $0.003 \%$ / PSU & $34.5-35.3 \mathrm{PSU}$ & $0.002 \%$ & $\begin{array}{l}\text { Antonov et al. 2010, } \\
\text { Young et al. 2013 }\end{array}$ \\
\hline$\delta^{13} \mathrm{C}$ of DIC on $\varepsilon_{\mathrm{p}}$ & $0.99 \%$ / \% & $1.25-1.45 \%$ & $0.20 \%$ & $\begin{array}{l}\text { Quay et al. 2003, } \\
\text { Young et. al. } 2013\end{array}$ \\
\hline $\mathrm{pCO}_{2}$ on $\varepsilon_{\mathrm{p}}$ & $0.0003 \%_{0} / \mathrm{ppm}$ & $20 \mathrm{ppm}$ & $0.006 \%$ & $\begin{array}{c}\text { Takahashi et al. 2009, } \\
\text { Young et al. 2013, } \\
\text { Keeling et al. 2004 }\end{array}$ \\
\hline $\begin{array}{c}\text { Species } \\
\text { fractionation }\left(\varepsilon_{\mathrm{f}}\right)\end{array}$ & $0.55 \%$ / $\%$ * & $\begin{array}{c}23.1-25.6 \% \\
\text { (Range for 0-200m) }\end{array}$ & $\begin{array}{c}1.37 \% 0 \\
\text { (not seasonal value) }\end{array}$ & $\begin{array}{c}\text { Rau et al. 1996, } \\
\text { Hernes and Benner } \\
2002 \text { (upper 200m) }\end{array}$ \\
\hline
\end{tabular}

* Calculated based off equations and values found in Rau et al. 1996. 


\section{Supplemental References:}

Antonov, J.I., Seidov, D., Boyer, T.P., Locarnini, R.A., Mishonov, A. V., Garcia, H.E., Baranova, O.K., Zweng, M.M., Johnson, D.R., 2010. World Ocean Atlas 2009, Volume 2:

Salinity, NOAA Atlas NESDIS 69. 10.1182/blood-2011-06-357442

Arellano-Torres, E., 2010. Paleoceanography of the https://doi.org/Eastern Tropical North Pacific on Millennial Timescales. Univ. Edinburgh. Dissertation: https://www.era.lib.ed.ac.uk/handle/1842/4634

Blaauw, M., Christen, J.A., 2011. Flexible paleoclimate age-depth models using an autoregressive gamma process. Bayesian Anal. 6, 457-474. https://doi.org/10.1214/11BA618

Chang, A.S., Pedersen, T.F., Hendy, I.L., 2008. Late Quaternary paleoproductivity history on the Vancouver Island margin, western Canada: a multiproxy geochemical study. Can. J. Earth Sci. 45, 1283-1297. https://doi.org/10.1139/E08-054

Dore, J.E., Lukas, R., Sadler, D.W., Church, M.J., Karl, D.M., 2009. Physical and biogeochemical modulation of ocean acidification in the central North Pacific. Proc. Natl. Acad. Sci. 106, 12235-12240. https://doi.org/10.1073/pnas.0906044106

Druffel, E.R.M., Griffin, S., Guilderson, T.P., Kashgarian, M., Southon, J., Schrag, D.P., 2001. Changes of subtropical North Pacific radiocarbon and correlation with climate variability. Radiocarbon 43(1) 15-25. https://doi.org/10.1017/S0033822200031593

Dubois, N., Kienast, M., Kienast, S., Normandeau, C., Calvert, S.E., Herbert, T.D., Mix, A., 2011. Millennial-scale variations in hydrography and biogeochemistry in the Eastern Equatorial Pacific over the last 100 kyr. Quat. Sci. Rev. 30, 210-223. https://doi.org/10.1016/j.quascirev.2010.10.012 
Emmer, E., Thunell, R.C., 2000. Nitrogen isotope variations in Santa Barbara Basin sediments: Implications for denitrification in the eastern tropical North Pacific during the last 50,000 years. Paleoceanography 15, 377-387. https://doi.org/10.1029/1999PA000417

Ganeshram, R.S., Pedersen, T.F., Calvert, S.E., McNeill, G.W., Fontugne, M.R., 2000. Glacialinterglacial variability in denitrification in the world's oceans: Causes and consequences. Paleoceanography 15, 361-376. https://doi.org/10.1029/1999PA000422

Ganeshram, R.S., Pedersen, T.F., Calvert, S.E., Murray, J.W., 1995. Large changes in oceanic nutrient inventories from glacial to interglacial periods. Nature 376, 755-758. https://doi.org/10.1038/376755a0

Guilderson, T.P., McCarthy, M.D., Dunbar, R.B., Englebrecht, a., Roark, E.B., 2013. Late Holocene variations in Pacific surface circulation and biogeochemistry inferred from proteinaceous deep-sea corals. Biogeosciences 10, 6019-6028. https://doi.org/10.5194/bg$10-6019-2013$

Hendy, I.L., Pedersen, T.F., 2006. Oxygen minimum zone expansion in the Eastern Tropical North Pacific during deglaciation. Geophys. Res. Lett. 33, 1-5. doi:10.1029/2006GL025975

Hendy, I.L., Pedersen, T.F., Kennett, J.P., Tada, R., 2004. Intermittent existence of a southern Californian upwelling cell during submillennial climate change of the last $60 \mathrm{kyr}$. Paleoceanography 19, 1-15. https://doi.org/10.1029/2003PA000965

Hernes, P.J., Benner, R., 2002. Transport and diagenesis of dissolved and particulate terrigenous organic matter in the North Pacific Ocean. Deep. Res. Part I Oceanogr. Res. Pap. 49, 2119 2132. https://doi.org/10.1016/S0967-0637(02)00128-0

Hinga, K.R., Arthur, M.A., Pilson, M.E.Q., Whitaker, D., 1994. Carbon isotope fractionation by marine phytoplankton in culture: The effects of $\mathrm{CO}_{2}$ concentration, $\mathrm{pH}$, temperature, and 
species. Global Biogeochem. Cycles 8, 91-102. https://doi.org/10.1029/93GB03393

Jia, G., Li, Z., 2011. Easterly denitrification signal and nitrogen fixation feedback documented in the western Pacific sediments. Geophys. Res. Lett. 38, 1-4. https://doi.org/10.1029/2011GL050021

Kao, S.J., Liu, K.K., Hsu, S.C., Chang, Y.P., Dai, M.H., 2008. North Pacific-wide spreading of isotopically heavy nitrogen during the last deglaciation: Evidence from the western Pacific. Biogeosciences 5, 1641-1650. https://doi.org/10.5194/bg-5-1641-2008

Keeling, C.D., Brix, H., Gruber, N., 2004. Seasonal and long-term dynamics of the upper ocean carbon cycle at Station ALOHA near Hawaii. Global Biogeochem. Cycles 18, 1-26. https://doi.org/10.1029/2004GB002227

Kienast, M., 2000. Unchanged nitrogen isotopic composition of organic matter in the South China Sea during the last climatic cycle: Global implications. Paleoceanography 15, 244 253. https://doi.org/10.1029/1999PA000407

Kienast, M., Lehmann, M.F., Timmermann, A., Galbraith, E., Bolliet, T., Holbourn, A., Normandeau, C., Laj, C., 2008. A mid-Holocene transition in the nitrogen dynamics of the western equatorial Pacific: Evidence of a deepening thermocline? Geophys. Res. Lett. 35, 1-5. https://doi.org/10.1029/2008GL035464

Kienast, S.S., Calvert, S.E., Pedersen, T.F., 2002. Nitrogen isotope and productivity variations along the northeast Pacific margin over the last 120 kyr: Surface and subsurface paleoceanography. Paleoceanography 17, 7-1-7-17. https://doi.org/10.1029/2001PA000650

Langton, S.J., Linsley, B.K., Robinson, R.S., Rosenthal, Y., Oppo, D.W., Eglinton, T.I., Howe, S.S., Djajadihardja, Y.S., Syamsudin, F., 2008. 3500 yr record of centennial-scale climate variability from the Western Pacific Warm Pool. Geology 36, 795-798. 
https://doi.org/10.1130/G24926A.1

Locarini, R.A., Mishonov, A. V., Antonov, J.I., Boyer, T.P., Garcia, H.E., Baranova, O.K., Zweng, M.M., Johnson, D.R., 2010. World Ocean Atlas 2009, Volume 1: Temperature., World. https://doi.org/10.1182/blood-2011-06-357442

McKay, J.L., Pedersen, T.F., Kienast, S.S., 2004. Organic carbon accumulation over the last 16 kyr off Vancouver Island, Canada: Evidence for increased marine productivity during the deglacial. Quat. Sci. Rev. 23, 261-281. https://doi.org/10.1016/j.quascirev.2003.07.004

Pichevin, L.E., Ganeshram, R.S., Francavilla, S., Arellano-Torres, E., Pedersen, T.F., Beaufort, L., 2010. Interhemispheric leakage of isotopically heavy nitrate in the eastern tropical Pacific during the last glacial period. Paleoceanography 25, 1-15. https://doi.org/10.1029/2009PA001754

Pichevin, L.E., Reynolds, B.C., Ganeshram, R.S., Cacho, I., Pena, L., Keefe, K., Ellam, R.M., 2009. Enhanced carbon pump inferred from relaxation of nutrient limitation in the glacial ocean. Nature 459, 1114-1117. https://doi.org/10.1038/nature08101

Quay, P., Sonnerup, R., Westby, T., Stutsman, J., McNichol, A., 2003. Changes in the ${ }^{13} \mathrm{C} /{ }^{12} \mathrm{C}$ of dissolved inorganic carbon in the ocean as a tracer of anthropogenic $\mathrm{CO}_{2}$ uptake. Global Biogeochem. Cycles 17, 1004, 1-20. https://doi.org/10.1029/2001GB001817

Rafter, P.A., Charles, C.D., 2012. Pleistocene equatorial Pacific dynamics inferred from the zonal asymmetry in sedimentary nitrogen isotopes. Paleoceanography $27,1-8$. https://doi.org/10.1029/2012PA002367

Rau, G.H., Riebesell, U., Wolf-Gladrow, D., 1996. A model of photosynthetic ${ }^{13} \mathrm{C}$ fractionation by marine phytoplankton based on diffusive molecular $\mathrm{CO}_{2}$ uptake. Mar. Ecol. Prog. Ser. 133, 275-285. https://doi.org/10.3354/meps133275 
Rau, G.H., Takahashi, T., Des Marais, D.J., 1989. Latitudinal variations in plankton $\delta^{13}$ C: implications for $\mathrm{CO}_{2}$ and productivity in past oceans. Nature $341,516-518$. https://doi.org/10.1038/341516a0

Rau, G.H., Takahashi, T., Desmarais, D.J., Repeta, D.J., Martin, J.H., 1992. The relationship between $\delta^{13} \mathrm{C}$ of organic matter and $\left[\mathrm{CO}_{2}(\mathrm{aq})\right]$ in ocean surface water: Data from a JGOFS site in the northeast Atlantic Ocean and a model. Geochim. Cosmochim. Acta 56, 14131419. https://doi.org/10.1016/0016-7037(92)90073-R

Reimer, P.J., Brown, T. a, Reimer, R.W., 2004. Discussion: Reporting and Calibration of PostBomb 14C Data. Radiocarbon 46, 1299-1304. https://doi.org/10.2458/azu_js_rc.46.4183

Reimer, P.J., Bard, E., Bayliss, A., Beck, J.W., Blackwell, P.G., Ramsey, C.B., Buck, C.E., Cheng, H., Edwards, R.L., Friedrich, M., Grootes, P.M., Guilderson, T.P., Haflidason, H., Hajdas, I., Hatté, C., Heaton, T.J., Hoffmann, D.L., Hogg, A.G., Hughen, K.A., Kaiser, K.F., Kromer, B., Manning, S.W., Niu, M., Reimer, R.W., Richards, D.A., Scott, E.M., Southon, J.R., Staff, R.A., Turney, C.S.M., van der Plicht, J., 2013. IntCal13 and Marine13 Radiocarbon Age Calibration Curves 0-50,000 Years cal BP. Radiocarbon 55, 1869-1887. https://doi.org/10.2458/azu_js_rc.55.16947

Roark, E.B., Guilderson, T.P., Dunbar, R.B., Fallon, S.J., Mucciarone, D.A., 2009. Extreme longevity in proteinaceous deep-sea corals. Proc. Natl. Acad. Sci. U. S. A. 106, 5204-8. https://doi.org/10.1073/pnas.0810875106

Robinson, R.S., Martinez, P., Pena, L.D., Cacho, I., 2009. Nitrogen isotopic evidence for deglacial changes in nutrient supply in the eastern equatorial Pacific. Paleoceanography 24, PA4213, 1-12. https://doi.org/10.1029/2008PA001702

Stuiver, M., Polach, H.A., 1977. Discussion Reporting of ${ }^{14}$ C Data. Radiocarbon 19, 355-363. 
https://doi.org/10.1017/S0033822200003672

Stuiver, M., Reimer, P.J., and Reimer, R.W., 2017, CALIB 7.0.2 Program available at http://calib.org, accessed 2017.

Takahashi, T., Sutherland, S.C., Wanninkhof, R., Sweeney, C., Feely, R.A., Chipman, D.W., Hales, B., Friederich, G., Chavez, F., Sabine, C., Watson, A., Bakker, D.C.E., Schuster, U., Metzl, N., Yoshikawa-Inoue, H., Ishii, M., Midorikawa, T., Nojiri, Y., Körtzinger, A., Steinhoff, T., Hoppema, M., Olafsson, J., Arnarson, T.S., Tilbrook, B., Johannessen, T., Olsen, A., Bellerby, R., Wong, C.S., Delille, B., Bates, N.R., de Baar, H.J.W., 2009. Climatological mean and decadal change in surface ocean $\mathrm{pCO}_{2}$, and net sea-air $\mathrm{CO}_{2}$ flux over the global oceans. Deep. Res. Part II Top. Stud. Oceanogr. 56, 8-10, 554-577. https://doi.org/10.1016/j.dsr2.2008.12.009

Tesdal, J.E., Galbraith, E.D., Kienast, M., 2013. Nitrogen isotopes in bulk marine sediment: Linking seafloor observations with subseafloor records. Biogeosciences 10, 101-118. https://doi.org/10.5194/bg-10-101-2013

Thunell, R.C., Kepple, A.B., 2004. Glacial-Holocene $\delta 15 \mathrm{~N}$ record from the Gulf of Tehuantepec, Mexico: Implications for denitrification in the eastern equatorial Pacific and changes in atmospheric $\mathrm{N}_{2} \mathrm{O}$. Global Biogeochem. Cycles 18, 1-12. https://doi.org/10.1029/2002GB002028

Vogel, J.S., Nelson, D.E., Southon, J.R., 1987. ${ }^{14} \mathrm{C}$ background levels in an accelerator mass spectrometry system. Radiocarbon 29, 323-333. https://doi.org/10.1017/S0033822200043733

Young, J.N., Bruggeman, J., Rickaby, R.E.M., Erez, J., Conte, M., 2013. Evidence for changes in carbon isotopic fractionation by phytoplankton between 1960 and 2010. Global 
Biogeochem. Cycles 27, 505-515. https://doi.org/10.1002/gbc.20045 